Winter 2011

\title{
Abuse of Power and Corruption in Kenya: Will the New Constitution Enhance Government Accountability
}

Migai Akech

University of Nairobi

Follow this and additional works at: https://www.repository.law.indiana.edu/ijgls

Part of the Constitutional Law Commons, and the International Law Commons

\section{Recommended Citation}

Akech, Migai (2011) "Abuse of Power and Corruption in Kenya: Will the New Constitution Enhance Government Accountability," Indiana Journal of Global Legal Studies: Vol. 18 : Iss. 1 , Article 15. Available at: https://www.repository.law.indiana.edu/ijgls/vol18/iss1/15

This Article is brought to you for free and open access by the Law School Journals at Digital Repository @ Maurer Law. It has been accepted for inclusion in Indiana Journal of Global Legal Studies by an authorized editor of Digital Repository@ Maurer Law. For more information, please contact rvaughan@indiana.edu.

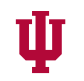

JEROME HALL LAW LIBRARY

INDIANA UNIVERSITY

Maurer School of Law
Blooming ton 


\title{
Abuse of Power and Corruption in Kenya: Will the New Constitution Enhance Government Accountability?
}

\author{
MIGAI AKECH ${ }^{*}$
}

ABSTRACT

This article suggests that corruption in the Kenyan government is largely an institutional problem, rather than a cultural one. It attributes such corruption to the predominance of arbitrary power, especially in the statutory (as opposed to constitutional) order. The statutory order grants executive, legislative, and judicial actors broad powers without establishing effective procedural mechanisms to circumscribe their exercise. In the absence of effective regulation, law often aids the abuse of power and corruption. Although the new constitution establishes principles and mechanisms that may enhance government accountability, the statutory order must be aligned with the values and principles of this new constitution if abuse of power and corruption are to be curbed.

\section{INTRODUCTION}

Kenya has made significant strides toward realizing meaningful democracy since the inception of reform initiatives in the early 1990 s. As a result of these democratization initiatives, the powers of the executive have been curtailed, and the legislature and the judiciary now enjoy considerable autonomy. ${ }^{1}$ Despite these significant gains, abuse of power and government corruption continue to thrive. As this article will show, the subversion of the electoral process that led to the outbreak of violence following the results of the highly contentious presidential

* Associate Professor, School of Law, University of Nairobi, Kenya. This article is the product of a Reagan-Fascell research fellowship at the National Endowment for Democracy (NED), October 2009-February 2010. I am grateful to the NED for research support. The views expressed in the article are my own, and do not necessarily reflect those of the NED or its staff.

1. See infra Part III.

Indiana Journal of Global Legal Studies Vol. 18 \#1 (Winter 2011)

(C) Indiana University Maurer School of Law 
election of December 2007 can partly be attributed to abuse of power. ${ }^{2}$ Far from abating, corruption seems to be increasing, as is clearly demonstrated by the recent scandals involving the importation of maize ${ }^{3}$ and oil ${ }^{4}$ and the embezzlement of the free primary education fund. ${ }^{5}$

In addition, abuse of power and corruption are no longer solely attributable to the executive. There are widespread and credible allegations that the legislature and the judiciary are also abusing their powers and engaging in, or facilitating, corruption. ${ }^{6}$ These allegations have led to questions about the ability and legitimacy of these branches to hold the executive to account. For example, there is a perception that legislators are no less corrupt than the executive actors they purport to hold accountable. ${ }^{7}$ Further, the legislature's ability to function as a watchdog is compromised because some of its key committees are headed by legislators who have been implicated in corruption scandals. There are also concerns that legislators are influenced by special interests and may not be credible guardians of the public interest.

The judiciary is equally culpable. Due to allegations of abuse of power and corruption, significant segments of the citizenry perceive the judiciary as having lost its legitimacy as a dispute resolution forum. For example, the breakdown of law and order in the aftermath of the results

2. Kenya descended into anarchy on December 30, 2007, after the Electoral Commission announced the results of the presidential election. Supporters of the Orange Democratic Movement (ODM) took to the streets in violent protest against the Electoral Commission of Kenya's declaration of President Mwai Kibaki as the winner of the presidential election. For all intents and purposes, state authority consequently collapsed in the political strongholds of the ODM. In many cases, the supporters of the ODM maimed and killed the supporters of President Kibaki's Party of National Unity (PNU). The supporters of the PNU responded in kind, and likewise maimed and killed ODM supporters living in their midst. In a bid to contain this orgy of violence, the government's security forces responded with great brutality. It is estimated that over 1,000 people died and 300,000 people were displaced from their homes as a result of the post-election violence.

3. See Afr. CTR. For Open Governance, The MaIze Scandal (Dec. 2009), available at http://www.africog.org/reports/Maize\%20Report.pdf (describing in vivid detail the underpinnings of the Kenyan maize scandal and the corruption associated with it).

4. See Afr. CTr. For OPEn Governance, ANALYsis OF The Triton OIL Scandal (July 2009), available at http:/www.africog.org/reports/Africog\%20newsletter-triton.pdf (offering an in-depth look at the Kenyan Oil Scandal).

5. See, e.g., David Aduda, Exposed: How Officials Looted Schools' Millions, DAILY NATION (Nairobi), Dec. 18, 2009, available at http://www.nation.co.ke/News//1056/826874/-/vo5w9o/-/index.html (recounting how 103 million Kenyan shillings were lost to embezzlement by senior officials, depriving the country's " 20,000 primary, 4,000 secondary, 37 technical training institutions, and 116 special learning centres.").

6. See, e.g., MPs in 'Most Corrupt' League, DAILY NATION (Nairobi), Dec. 10, 2005; REPUBLIC OF KENYA, FINAL REPORT OF THE TASK FORCE ON JUDICIAL REFORMS 74 (2010).

7. See, e.g., Njeri Rugene, Bribery in Kenya's Parliament, Dally NaTION (Nairobi), May 16, 2009, available at http://www.nation.co.ke/News/-/1056/599016/-/u6adu9/-/index.html. 
of the 2007 presidential election is partly attributable to the public's perception of the judiciary as partisan and unable to provide a civil avenue for the resolution of the disputes generated by the fiercely contested election.

Various explanations have been offered for the existence of corruption in government. "Democratization may lead to incentives for corruption, especially in the process of campaigning for election."8 For example, Michela Wrong suggests that corruption is prevalent in Kenya because ethnic cabals believe that it is their "turn to eat" once they assume the reins of government. ${ }^{9}$ However, these explanations may be symptomatic of a much deeper problem, namely institutional failure. Dysfunctional or failed institutions often facilitate the abuse of power in government. Without denigrating the role cultural norms may play in encouraging corruption, this article adopts the approach of institutional theorists who view corruption as "politically endogenous."10 From this perspective, institutional mechanisms that increase political accountability-for example, by encouraging punishment of corrupt individuals or reducing the informational problems related to government activities-may reduce the incidence of corruption. ${ }^{11}$

This article suggests that corruption in Kenyan government is largely an institutional problem, rather than a cultural one. That is, corruption can be attributed to the predominance of arbitrary power, especially in the statutory (as opposed to constitutional) order. The Kenyan statutory order grants executive, legislative, and judicial actors broad powers without establishing effective procedural mechanisms to circumscribe their exercise. In the absence of effective regulation, law often aids the abuse of power and corruption. In other words, "in the absence of fear of penalty or sanctions, there is nothing to deter [those who wield power from] fraudulently enriching themselves" and violating the law. ${ }^{12}$ In this scenario, government actors often disregard the prescriptions of law, especially where they view legal requirements as hindering the attainment of short-term political objectives or other ends. Because law is dispensed with whenever it becomes convenient to

8. See Inge Amundsen, Political Corruption: An Introduction to the Issues 18 (Chr. Michelsen Inst., Working Paper No. 7, 1999).

9. See Michela Wrong, IT'S OUR Turn to Eat: The Story of a Kenyan Whistle BLOWER (2009).

10. See Wonbin Cho, What Are the Origins of Corruption in Africa? Culture or Institution 3 (Feb. 15, 2009), available at http:/www.allacademic.com/meta/p311499 _index.html (paper presented at the International Studies Association 2009 Convention).

11. See Daniel Lederman et al., Accountability and Corruption: Political Institutions Matter 3-4 (World Bank Policy Research, Working Paper No. 2708, Nov. 2001).

12. N.G. Egbue, Africa. Cultural Dimensions of Corruption and Possibilities for Change, 12 J. Soc. SCI. 83, 84 (2006). 
do iso, a culture of impunity emerges where law ceases to be authoritative.

Furthermore, the President, government ministers, and senior public servants often use the law to intimidate their juniors into silence or into obeying illegal commands, largely because of the absence of accountability mechanisms. Indeed, junior public servants are often unwilling accomplices to abuses of power or corruption. Moreover, until the promulgation of a new constitution in August 2010, the law did not restrict the President's ability to make decisions without consulting the cabinet or undermining the independence of the judiciary, nor did it restrict the Chief Justice's ability to compromise the decisional independence of judges, nor legislators' ability to become hired mercenaries for the highest bidder. In the case of the legislature, the failure to institutionalize codes of conduct functions as a license for legislators to breach conflict of interest rules with impunity. In addition, state secrecy laws such as the Official Secrets Act ${ }^{13}$ have ensured that the citizenry have little or no information about the activities of government. Invariably, the citizenry only learn of abuses of power and corruption long after they have occurred, by which time the damage caused is nearly irreparable. Even new laws enacted to aid the fight against corruption, such as the Public Officer Ethics Act, ${ }^{14}$ may actually be used to strengthen the hand of power wielders, who often interpret such laws in a manner that enhances their ability to intimidate public servants. In these circumstances, constitutional reform must be accompanied by comprehensive democratization of the legal order.

Using examples of corruption and abuses of power, this article examines how governmental power is exercised in Kenya and analyzes the potential of the new constitution-which took effect on August 27, 2010 , following approval by the citizenry at a referendum held on August 4, 2010 - to enhance government accountability. This article is motivated by a concern that democratization initiatives have not been adequately concerned with regulation of the exercise of power within the three branches of government. Part I examines the limitations of representative democracy and the need for the establishment of institutions for the day-to-day accountability of government. Using illustrations of abuse of power and corruption, Part II explores how power is exercised within the three branches of government in Kenya. Part III analyzes the provisions of the new constitution dealing with the branches of government. Part IV concludes with observations on the

13. Official Secrets Act, (1968) Cap. 187 (Kenya).

14. Public Officer Ethics Act, (2009) Cap. 183 (Kenya). 
need to democratize the statutory order ${ }^{15}$ to facilitate the realization of the new constitution, and suggests administrative law reform as being critical to this endeavor.

\section{REPRESENTATIVE DEMOCRACY AND GOVERNMENT ACCOUNTABILITY}

\section{A. The Idea of Accountability}

The practice of representative democracy-in which the citizenry delegate their sovereignty to popularly elected representatives, who in turn delegate their authority to bureaucrats-does not always ensure that governmental power is only used for its intended purposes, namely the protection of the rights of citizens and the pursuit of the public good.16 This is because the people who govern are not always accountable to the governed. In order to appreciate the limitations of representative democracy, we need to understand the meaning of the term accountability and how it can be realized.

Accountability may be defined as "a social relationship in which an actor feels an obligation to explain and to justify his or her conduct to some significant other." 17 This definition implies a relationship in which "some actors have the right to hold other actors to a set of standards, to judge whether they have fulfilled their responsibilities in light of these standards, and to impose sanctions if they determine that these responsibilities have not been met."18 In this relationship the "accountor" has an obligation to explain and justify his or her conduct to the "accountee." 19 Explaining and justifying conduct entails different activities, such as providing information about performance, debating whether the conduct was proper, and judging of the accountor by the accountee. ${ }^{20}$ Furthermore, after judging the conduct of the accountor, the accountee may either choose to reward the accountor in case of adequate performance, or impose sanctions in case of poor performance. $^{21}$ Though accountability always operates ex post, that is, after the conduct of the accountor, "accountability mechanisms can exert ex ante effects, since the anticipation of sanctions may deter the

15. The statutory order consists of statutes, regulations, codes of conduct, and practices of governmental institutions.

16. Ruth W. Grant \& Robert O. Keohane, Accountability and Abuses of Power in World Politics, 99 AM. POL. SCI. REv. 29, 32 (2005).

17. Mark Bovens, Public Accountability, in THE OXFORD HANDBOOK OF PUBLIC MANAGEMENT 182, 184 (Ewan Ferlie et al. eds., 2007).

18. Grant \& Keohane, supra note 16, at 29.

19. Bovens, supra note 17 , at $184-85$.

20. Id.

21. Id. at 185 . 
powerful from abusing their positions in the first place."22

In the context of democracy, accountability institutions or mechanisms serve four primary ends. First, these mechanisms make it possible for the public to call those in public office to account. ${ }^{23}$ From this perspective, representative democracy is a chain of principal-agent relationships, where the people (the primary principals) have transferred their sovereignty to popular representatives, who, in turn, have transferred their authority to ministers and public servants. ${ }^{24}$ Accountability mechanisms enable the people to hold these agents accountable for the exercise of these delegated powers. Under ideal conditions, the people would have sufficient information to enable them to scrutinize the conduct of these agents. If the people were to find such conduct to be unsatisfactory, they could then indicate their displeasure by voting the offending representatives out of office.

Second, accountability mechanisms enable the people to prevent abuses of power and corruption. ${ }^{25}$ These mechanisms enable the exposure of unauthorized, illegitimate, or unjust exercises of governmental power. ${ }^{26}$ Third, accountability mechanisms serve the purpose of keeping the agents of the people on their toes, by constantly keeping the agents aware of the fact that they will be called upon to account for their actions, thereby helping the people to prevent abuses of power and corruption. ${ }^{27}$ Finally, accountability mechanisms serve the important goal of legitimizing government in the perception of the citizenry by promoting acceptance of government authority and confidence in the government. ${ }^{28}$

\section{B. Realizing Accountability}

How, then, is accountability to be realized? There are different accountability arrangements depending on whether the polity in question has adopted a parliamentary or presidential system of government or a hybrid of these two. A parliamentary system is a system of government in which the executive (the prime minister and the cabinet) is chosen by and is accountable to the legislature. ${ }^{29}$ It is

\footnotetext{
22. Grant \& Keohane, supra note 16, at 30.

23. Bovens, supra note 17 , at 192.

24. $I d$.

25. Id. at 193.

26. Grant \& Keohane, supra note 16, at 30.

27. See Bovens, supra note 17 , at 193.

28. Id.

29. Kaare Strom, Delegation and Accountability in Parliamentary Democracies, 37 EUR. J. POL. RES. 261, 264 (2000).
} 
also defined by the following features: the sovereignty of the legislature, the unification or fusion of legislative and executive power, the concentration of political power in a collective and responsible cabinet, and the accountability of ministers to the legislature. ${ }^{30} \mathrm{~A}$ presidential system of government is defined as one in which executive power is exercised by a President who is elected by the people (or an electoral college, as in the United States) ${ }^{31}$ Here, the President draws power directly from the people. The main difference between the two systems is that presidentialism is based on the separation of executive and legislative powers, while parliamentarism is based on the fusion of executive and legislative powers. ${ }^{32}$ In addition, whereas policy making is largely the responsibility of the executive in parliamentary systems, it is shared by the President and the legislature in presidential systems. Hybrid, or semipresidential systems of government, are those that combine features of parliamentarism and presidentialism in the sense that they have both "a popularly-elected fixed-term president and a prime minister and cabinet responsible to the legislature." 33

Their differences notwithstanding, these representative systems of government are all defined by the delegation of power from voters to elected representatives and then to delegates of the latter. The people therefore need to ensure that the elected representatives and their delegates are answerable for their exercise of governmental power. Accordingly, various mechanisms have been established to facilitate the accountability of the three branches of government.

\section{Accountability of the Executive and Public Service}

In parliamentary systems, especially those based on the Westminster model of government, executive accountability has largely revolved around the doctrine of ministerial responsibility, which denotes the accountability of government ministers to the legislature. In this system, ministers are viewed as agents of the legislature and are accountable to the legislature for the exercise of their delegated powers.

30. R.A.W. Rhodes, Is Westminster Dead in Westminster (and Why Should We Care)?, Inaugural Lecture in the Australia and New Zealand School of Government-Australian National University Public Lecture Series 3-4 (Feb. 23, 2005), available at http://www.rodrhodes.com.au/wp/wp-content/uploads/2008/04/anzsog-lecture.pdf.

31. Scott Mainwaring \& Matthew S. Shugart, Juan Linz, Presidentialism, and Democracy, 29 COMP. POL. 449, 449 (1997).

32. See José Antonio Cheibub \& Fernando Limongi, Democratic Institutions and Regime Survival: Parliamentary and Presidential Democracies Reconsidered, 5 ANN. REV. POL. SCI. 151, 152 (2002).

33. Robert Elgie, The Perils of Semi-Presidentialism. Are they Exaggerated?, 15 DEMOCRATIZATION 49, 51 (2008). 
Ministerial responsibility requires ministers to take corporate responsibility for the activities of their departments, a process that entails answering questions from the public (which are posed to the ministers by ordinary legislators) and rectifying any mistakes that come to light. ${ }^{34}$ While ministers are required to explain or justify their departments' actions, the concept of ministerial responsibility does not impose any obligation on ministers to take personal responsibility for departmental activities or resign on account of the failures of their subordinates. ${ }^{35}$

The doctrine of ministerial responsibility imposes no legal obligation on ministers to resign where there is abuse of power or corruption in their departments. Even where ministers take political responsibility for abuse of power or corruption in their departments by accepting corporate blame or resigning, the question of which public servant "is exactly to blame usually lies buried behind a wall of official silence." ${ }^{36}$ In any case, satisfaction of the legislature is the "touchstone of accountability" in Westminster governmental systems. ${ }^{37}$ Accordingly, governmental departments are regarded as publicly accountable, provided the responsible minister furnishes the legislature with an explanation it deems satisfactory. Such accountability may be inadequate, however, especially where the legislature does not have sufficient information on the circumstances surrounding the governmental matter in question. Unless the legislature has effective mechanisms and resources for conducting investigations into the affairs of government, it has no alternative but to accept the explanations given by such a minister, however inadequate. Furthermore, where the ruling party has a majority in the legislature, legislative scrutiny of governmental actions may be perfunctory because opposition parties in such scenarios have little or no power to hold government to account.

It should be noted that ministerial responsibility is only episodic. It does not demand active legislative supervision of government because there is a "reasonable likelihood" that instances of maladministration will come to the attention of legislators eventually. ${ }^{38}$ However, in view of the complexity of modern government, arguably many significant instances of maladministration may escape the attention of legislators.

34. Richard Mulgan, Westminster Accountabilities: Holding Power to Account in Modern Democracies 4 (Sept. 2006), available at http://www.vic.ipaa.org.au/document/ item/32 (paper presented at the 2006 Spotlight on Spring Street Seminar of the Institute of Public Administration Australia).

35. Id.

36. Mulgan, supra note 34 , at 7 .

37. Bruce Stone, Administrative Accountability in the 'Westminster' Democracies: Towards a New Conceptual Framework, 8 GovernaNCE 505, 512 (1995).

38. Id. at 511 . 
In addition, mechanisms that protect the confidentiality of governmental matters, such as state secrecy laws, may frustrate efforts of the public to hold government accountable.

Ministerial responsibility is buttressed by the concept of collective responsibility of the cabinet to the legislature, which obligates ministers to defend government policy. Thus a minister who disagrees with government policy should resign if he or she intends to oppose such policy. This means that if a government is defeated on a vote of no confidence, ${ }^{39}$ all of the ministers must resign, giving the people an opportunity to delegate their power to a new government.

In presidential systems, it is argued that the dispersal of executive and legislative power enables friction between the legislative and executive branches of government, thereby facilitating the accountability of the executive. ${ }^{40}$ This dispersal of power prevents corruption and abuse of power by enabling the legislature to contest actions of the executive. ${ }^{41}$ As in parliamentary systems, the executive in presidential systems is also accountable to the legislature, which establishes committees to oversee the performance of the executive. Another notable distinction between the two systems concerns the accountability of public servants. Whereas public servants in parliamentary systems are primarily accountable to a single principal (that is, the minister), public servants in presidential systems are accountable to multiple principals (specifically, the President and the legislature). ${ }^{42}$

Ensuring executive accountability is an even more daunting task in hybrid systems. Here, the potential for conflict between the President and prime minister may blur established lines of accountability, ${ }^{43}$ with the result that significant instances of abuse of power or corruption will go unchecked. This is likely in situations of "cohabitation," 44 in which the legislature is not cohesive and does not act with one voice. Cohabitation denotes a situation in which "the president is from one party or political grouping and the prime minister is from an opposed

39. A vote of no confidence is a motion that opposition parties put before the legislature in the hope of defeating or weakening the government.

40. See Neal Kumar Katyal, Internal Separation of Powers: Checking Today's Most Dangerous Branch from Within, 115 YALE L.J. 2314 (2006).

41. N.W. Barber, Prelude to the Separation of Powers, 60 CAMBRIDGe L.J. 59, 60-61 (2001).

42. Strøm, supra note 29 , at 269-70.

43. Oleh Protsyk, Intra-Executive Competition Between President and Prime Minister: Patterns of Institutional Conflict and Cooperation Under Semi-Presidentialism, 54 PoL. STUD. 219, 220-21 (2006).

44. See Elgie, supra note 33. 
party or grouping." 45 In such cases of intra-executive conflict, abuses of power or corruption by or involving public servants may also escape scrutiny. Accountability deficits may also arise in hybrid systems in which the legislature is dominated by one party because there will be no effective check on the executive.

In all three systems, unelected bureaucrats often exercise the executive powers. ${ }^{46}$ Meanwhile, the legislature has neither the time nor the resources to check the powers of the executive. Perhaps even more significantly, there is often an information asymmetry ${ }^{47}$ that favors bureaucrats, with the result that the legislature is, in many cases, unable to oversee the exercise of power by public servants in a meaningful manner. 48

Many democracies have deemed it necessary to establish auxiliary institutions, which seek to enhance the day-to-day accountability of the executive. In this regard, institutions that prevent or punish maladministration are particularly useful, especially because they regulate the interactions of politicians and public servants in the exercise of power. Examples of such institutions are hearings of committees of the legislature in which ministers or public servants appear and testify, obligations on the public service to report to the legislature, appointments of ombudsmen, and creation of public service commissions. ${ }^{49}$ These institutions are especially notable in that-unlike the doctrine of ministerial responsibility - they regard public servants as independent of the elected government and as "the guardians of a public trust underlying the exercise of all public authority." 50 Thus, even though public servants are agents of the current executive, they are ultimately accountable to the people for the exercise of their delegated powers. These special institutions of accountability serve two related functions: first, ensuring that the government always uses the public service solely to promote the public interest; and, second, ensuring that public servants do not use their positions to pursue private or partisan

45. Id. at 54 .

46. Mathew D. McCubbins et al., Administrative Procedures as Instruments of Political Control, 3 J.L. EcON. \& ORG. 243, 243 (1987).

47. The legislature can only hold government to account if it is sufficiently informed about the goings-on in government. But it requires resources and time to investigate conduct of the executive. In the absence of such resources in countries such as Kenya, an information asymmetry arises since bureaucrats, who implement the policy decisions of government, will then have much better information than the legislature.

48. See, e.g., Bruce Stone, Administrative Accountability in the 'Westminster' Democracies: Towards a New Conceptual Framework, 8 GOVERNANCE 505, 511 15 (1995).

49. See Strom, supra note 29 , at 269.

50. Lorne Sossin, Speaking Truth to Power: The Search for Bureaucratic Independence in Canada, 55 U. TORONTO L.J. 1, 2 (2005). 
ends. Furthermore, these auxiliary institutions are typically characterized by procedural safeguards that circumscribe the exercise of power.

In Kenya, problems with the government's improper use of public service and public servants' abuse of their positions have occurred in the recent past. For example, a commission of inquiry established that in the months preceding the 2007 general elections, the head of Public Service and secretary to the cabinet ordered senior police officers to train a large number of their juniors so that they could act as agents for the ruling party. ${ }^{51}$ The commission of inquiry established that the role of these officers "was to disrupt polling and where possible ensure that government supporters amongst the candidates and voters prevailed." 52 It is important to ensure that the concept of public service neutrality does not facilitate either kind of abuse of power. Accordingly, public servants should not, in the pretext of preserving their impartiality, be prevented from exposing cases where the government is involved in illegal acts or corruption. In such cases, public servants have a duty to question or even "decline to follow instructions which are motivated by improper partisan interests." 53

Although public servants are agents of the government, they owe a higher duty to the public to observe the rule of law. ${ }^{54}$ As Lorne Sossin has argued, the "rule of law doctrine imposes a public trust obligation on public servants to ensure that the rule of law is respected and that government directions which are inconsistent with the rule of law are not followed."55 Should public servants choose to become whistleblowers in the process of performing this duty, they ought to be given sufficient legal protection. ${ }^{56}$ From this premise, public servants should not be prevented from disclosing violations of the rule of law, corruption, and abuses of power. ${ }^{57}$ Likewise, the concept of political neutrality should not, as is often the case, be used as a shield against public scrutiny of the actions of public servants on the pretext that "the regulation of the

51. See, e.g., REPORT OF THE COMM'N OF INQUIRY INTO POST-ELECTION VIOLENCE 40507 (2008) (Kenya), available at http://www.dialoguekenya.org/docs/PEVReport1.pdf [hereinafter WAKI REPORT].

52. Id. at 406.

53. LORNe SOSSIN, COMm'N OF INQUIRY INTO THE SPONSORSHIP PROGRAM AND ADVER. ACTIVITIES, DEFINING BOUNDARIES: THE CONSTITUTIONAL ARGUMENT FOR BUREAUCRATIC INDEPENDENCE AND ITS IMPLICATION FOR THE ACCOUNTABIITY OF THE PUBlic SERVICE 25,30 (2006), available at http://dsp-psd.pwgsc.gc.ca/Collection/GomerylL/Research Studies2/CISPAA_Vol2_2.pdf.

54. Id. at 37.

55. $I d$. at 38 .

56. See id. at 36.

57. See id. at 45-46. 
civil service is a matter for the political executive alone to resolve."58

\section{Accountability of the Legislature}

In the case of the legislature, a common argument is that the legislature is sovereign and should be left to regulate itself. In England, for example, critics often argue that "[ $t]$ he freedom of speech and debates and proceedings in Parliament are not to be impeached or questioned in any court or place outside of Parliament." 59 The claim is the fact that the legislature derives its power directly from the people, who can withdraw that power in an election should they wish, is a sufficient accountability measure. Further, one might argue that the legislature should be autonomous in its actions if it is to be an effective guardian of the public interest. In Westminster systems, this autonomy is asserted through the operation of the principle of parliamentary privilege, which allows the legislature to maintain internal autonomy from external actors such as the public, the executive, and the judiciary. ${ }^{60}$ Questions of how the legislature runs its affairs between elections are generally not asked. However, experience demonstrates that the legislature can also be influenced by private interests, and the making of public policy and law is often driven by strong and organized interest groups at the expense of the public interest. A need therefore arises to hold the legislature accountable.

Recognizing the fallibility of the legislature, countries such as the United Kingdom and Australia have established institutions that seek to enhance its day-to-day accountability. ${ }^{61}$ These accountability mechanisms are premised on the belief that legislators are not only political actors but are also "public officials who [ought to] exercise power for a public purpose."62 These accountability mechanisms also enhance public confidence in the legislature, in the sense that legislators should not only act for the right reasons, but also should appear to do so in the public eye. ${ }^{63}$ Accordingly, many legislatures have established ethics regimes that regulate the conduct of their members

58. Sossin, supra note 50 , at 15.

59. Dawn Oliver \& Gavin Drewry, Introduction to THE LAW AND PaRLIAMENT 1, 4 (Dawn Oliver \& Gavin Drewry eds., 1998).

60. See Barry K. Winetrobe, The Autonomy of Parliament, in THE LAW AND PARLIAMENT, supra note 59, at 14, 17-18.

61. Robert Kaye, Regulating Parliament: The Regulatory State Within Westminster 5 (Econ. \& Soc. Res. Council Ctr. for Analysis of Risk and Reg., Discussion Paper No. 13, 2003).

62. Id.

63. See, e.g., id. at 8. 
and maintain institutional integrity. ${ }^{64}$ For example, corruption and misconduct in the House of Commons in 1990s Great Britain led to the establishment of "an institutionalized system of standards, investigation and sanction."65 Thus the British House of Commons now has codified rules of conduct, a commissioner who acts as the principal ethics adviser and investigator, and a Standards and Privileges Committee that oversees the conduct of legislators and the work of the commissioner. ${ }^{66}$

\section{Accountability of the Judiciary}

In the case of the exercise of judicial power, the judiciary should remain autonomous because that is the only way in which it can effectively fulfill its democratic role. In short, the judiciary should regulate itself and the other branches of government should not interfere in its affairs. ${ }^{67}$ Adopting this mindset often leaves the exercise of power within the judiciary unchecked and explains why chief justices in commonwealth countries have immense and unaccountable powers. In Kenya, these powers of the Chief Justice may undermine the decisional independence of judicial officers. Further, maladministration in the judiciary, such as the misuse of public funds, may escape public scrutiny when the judiciary does not account to the other branches of government for the way it runs its administrative affairs. Indeed, public accountability mechanisms are even more important in the case of the judiciary.

Compared to the executive and legislative powers, judicial power is unique since it is exercised by judicial officers who are typically appointed and are therefore not accountable to the electorate in the way that members of the executive and the legislature are. ${ }^{68}$ In addition, because judges are typically unelected, the courts are often perceived as undemocratic and a threat to good government. ${ }^{69}$ Accordingly, although the judiciary plays the crucial role of limiting the will of the majority, its

64. Nicholas Allen, British Parliamentary Misconduct in the Early Twenty-First Century 12 (March 31, 2009), available at http:/www.psa.ac.uk/journals/pdf/5/2009/ Allen.pdf (draft prepared for the Annual Conference of the Political Studies Association).

65. Id. at 18 .

66. Id. at 18-19.

67. E.g., Harry T. Edwards, Regulating Judicial Misconduct and Divining "Good Behavior" for Federal Judges, 87 MICH. L. REV. 765, 765 (1989) (noting that "we have endeavored to preserve an independent judiciary as a "citadel of the public justice and the public security.").

68. Beverley McLachlin, Judicial Power and Democracy, 12 SING. ACAD. L.J. 311, 311 (2000).

69. Id. 
legitimacy is often contested.

In order to enhance the accountability and legitimacy of the judiciary, many countries have established judicial councils or commissions. ${ }^{70}$ While the specific role that judicial councils play tends to vary from country to country, they often provide mechanisms for circumscribing the exercise of judicial power. ${ }^{71}$ Typically, judicial councils have the following powers over judicial officers and paralegal staff: appointment; determining complaints, discipline, and removal; and managing, evaluating, and monitoring performance. ${ }^{72}$ These powers often facilitate effective regulation of the exercise of judicial power.

\section{ABUSE OF POWER AND CORRUPTION}

\section{A. Organization, Exercise, and Accountability of Executive Power}

Despite the establishment of numerous institutions seeking to enhance the accountability of the executive, the exercise of power in Kenya's executive branch has been characterized by significant abuse and rampant corruption. In order to understand why these new institutions have not enhanced the accountability of the executive, the executive's historical organization, exercise of power, and methods of accounting for its actions must be examined.

After gaining its independence in 1963, Kenya adopted a parliamentary system of government based on the Westminster model. ${ }^{73}$ In theory, the executive (consisting of a prime minister and a cabinet) was accountable to the legislature. In addition, the prime minister and the cabinet were supposed to implement public policy through a meritocratic, impartial, and politically neutral public (or civil) service. ${ }^{74}$ The Constitution of Kenya of 1963 (hereinafter, the Independence Constitution) made elaborate provisions to ensure the autonomy and neutrality of the public service. For example, it established an autonomous Public Service Commission (PSC) and put it in charge of recruitment, promotion, discipline, and dismissal. ${ }^{75}$ The Independence Constitution also imposed restrictions that ensured that members of the

70. Violaine Autheman \& Sandra Elena, Global Best Practices: Judicial Councils: Lessons from Europe and Latin America 1 (IFES Rule of Law White Paper Series, White Paper No. 2, 2004).

71. But see id. at 11 .

72. Id.

73. C. Odhiambo-Mbai, Public Service Accountability and Governance in Kenya Since Independence, 8 AFR. J. POL. SCI. 113, 118 (2003).

74. Id.

75. See id. at 138-39. 
PSC would neither be political figures nor public officers, as such figures might be indebted for their appointment to a political leadership position. ${ }^{76}$ Members of the PSC also were given security of tenure. ${ }^{77}$

However, Kenya quickly shifted to a presidential system of government following a series of constitutional amendments enacted in the $1960 \mathrm{~s}$, which consolidated power in the presidency by weakening the multiparty system, and gave the President control over critical governmental agencies such as the Public Service.

Until the promulgation of the new constitution in 2010, the executive consisted of the President, vice president, prime minister, two deputy prime ministers, and ministers of government. ${ }^{78}$ Together these officers made up the cabinet, whose function was "to aid and advise the president in the government of Kenya." 79 Further, the Independence Constitution (as amended) provided that the cabinet was "collectively responsible to the National Assembly for all things done by or under the authority of the president or the vice-president or any other minister in the execution of his office." 80 This provision of the constitution could be interpreted to mean that the President could only instruct the Public Service to implement policy decisions that had been made collectively and pursuant to deliberations of the cabinet.

In practice, however, the exercise of executive power was not constrained by the doctrine of collective responsibility precisely because this provision did not impose an obligation on the President to seek the aid and advice of the cabinet. ${ }^{81}$ For all intents and purposes, the President was an "executive with unshared responsibility for policy" and was perfectly entitled to bypass the authority of the cabinet. ${ }^{82}$ Indeed, collective responsibility did not imply collective power for decision making and merely obligated ministers to support and defend government policies, irrespective of whether they participated in their

76. See Constitution, art. 106(3) (1963) (Kenya).

77. ConstituTion, art. 106(7) (1963) (Kenya). Security of tenure here denotes the legal protection afforded to employees against dismissal without just cause.

78. Section 2 of the Sixth Schedule of the New Constitution provides that this arrangement will prevail until the next general election. In the succeeding paragraphs, I use the terms "Independence Constitution" and "New Constitution" to distinguish the constitution being replaced from the new one.

79. ConsTITUTION, art. 17(2) (1963) (Kenya).

80. Id. art. $17(3)$.

81. See B.O. NWABUeze, Presidentialism in Commonwealth Africa 43 (1974). But see id. at 199.

82. Id. at 199 (observing that under a parliamentary system of government, a prime minister cannot afford to bypass the cabinet, "as otherwise he would incur the accusation of wanting to subvert the Constitution, since he has a joint responsibility with the other ministers for government and its policies."). 
formulation. ${ }^{83}$ These provisions of the now-repealed Independence Constitution largely explain why successive presidents were accused of governing with so-called "kitchen cabinets." Indeed, the President often ignored the cabinet entirely or made important decisions affecting the portfolios of ministers without involving or informing them. ${ }^{84}$

Furthermore, although the prime minister was originally intended to have a more significant role in exercising executive power, the President ignored him in significant instances. ${ }^{85}$ Since the international mediation that followed the Electoral Commission's bungling of the 2007 presidential elections, Kenya began experimenting with a hybrid executive. The office of prime minister was created by an amendment to the Independence Constitution, which meant that, in theory, the President shared executive power with the prime minister. ${ }^{86}$ In practice, however, the President often bypassed the prime minister and instead exercised power through the office of the head of the Public Service, who was also secretary to the cabinet. As examined below, the office of the head of the Public Service oversaw the day-to-day administration of the Public Service, and it therefore possessed immense power. At the same time, the Independence Constitution now required the legislature to enact a statute setting out the powers of the prime minister. This statute, which was enacted as the National Accord and Reconciliation Act, conferred on the prime minister the "authority to co-ordinate and supervise the execution of the functions and affairs of the Government of Kenya." 87 This sounded like a powerful office; however, by working through the office of the head of the Public Service, the President effectively undermined the powers of the prime minister. ${ }^{88}$

The primary objective of the constitutional amendments of the 1960 s was to ensure presidential control of the Public Service. One amendment empowered the President to appoint members of the PSC without reference to anyone. ${ }^{89} \mathrm{~A}$ subsequent amendment enhanced the

83. Id. at 45 .

84. E.g., Kipkirui K’Telwa, Karua Resigns from Cabinet, STANDARD (Nairobi), Apr. 6, 2009 (describing how the President ignored a cabinet member, who was the Justice minister, when new judges were picked, leading the cabinet member to resign in protest).

85. E.g., Uproar as Kibaki Signs into Law the Controversial Media Bill, STANDARD (Nairobi), Jan. 3, 2009 (reporting on the President's signing of controversial legislation into law, despite the prime minister's assurances to the public that it would be returned to the parliament).

86. Constitution, art. 15A(1) (1963) (Kenya); Constitution of Kenya (Amendment) Act, No. 3 of 2008.

87. National Accord and Reconciliation Act, No. 4 of 2008, sched. 1 (Kenya).

88. See One Country, Two Presidents, NAIROBI Chronicle (June 14, 2009), http://nairobichronicle.wordpress.com/2009/06/14/one-country-two-presidents.

89. See CONSTITUTION, art. 106(2) (1963) (Kenya); Constitution of Kenya (Amendment) Act, No. 28 of 1964. 
President's control of the Public Service by giving him the power to constitute and abolish offices in the Public Service, to make appointments to any such office, and to terminate any such appointment. 90 The aggregate effect of these amendments made the Public Service totally subservient to the President. Once President Kenyatta assumed control over the Public Service, he soon began to undermine its independence. The principle of meritocracy was quickly set aside as the President filled key positions and effected promotions in the Public Service without due regard to merit. ${ }^{91}$ From the early $1980 \mathrm{~s}$ on, the permanence of the Public Service was undermined as "permanent secretaries and other senior public servants [were shuffled] from organization to organization without due regard to their suitability for the positions."92 In addition, it soon became common practice for the President "to recruit permanent secretaries and other senior public servants from outside the mainstream public service."93

Although the PSC was the main repository of the power to recruit, discipline, and dismiss public servants, the Independence Constitution provided that it could-subject to the approval of the Presidentdelegate these powers to any officers in the Public Service. ${ }^{94}$ Thus disciplinary matters were initially handled at the ministry level before being submitted to the PSC for final determination. In theory, the tenure of public servants depended on their adherence to a code of regulations, which was made under the Service Commissions Act ${ }^{95}$ and administered by the PSC. In practice, however, they served at "the pleasure of the President."96 Thus the President could, and often did, terminate their services at will. ${ }^{97}$ In addition, the government acknowledged that disciplinary cases took too long in ministries before they were submitted to the PSC for determination. ${ }^{98}$ Furthermore, the PSC's decisions were often not implemented, "thus causing a lot of

90. Constitution of Kenya (Amendment) (No. 3) Act, No. 28 of 1964.

91. Cf. Odhiambo-Mbai, supra note 73 , at 119 .

92. Id. at 132 .

93. Id.

94. Id. art. 107(1).

95. Pub. Serv. Comm'N, L.N. 28/2005, The Public Service Commission Regulations $\S 25$ (2005) (regulations set forth pursuant to The Service Commissions Act, (2008) Cap. $185 \S 13)$.

96. CONSTITUTION, art. 25(1) (1963) (Kenya).

97. J.B. OJWANG, CONSTITUTIONAL DEVELOPMENT IN KENYA: INSTITUTIONAL Adaptation AND Social Change 91 (1990).

98. Memorandum, Francis K. Muthaura, Permanent Sec'y, Sec'y to the Cabinet and Head of the Pub. Serv., Implementation of Delegated Powers and the Public Service Commission's Decisions (Feb. 13, 2007), available at http:/www.dpm.go.ke/index.php? option=com_docman\&task=doc_details\&gid=102\&Itemid=174. 
anxiety among the affected officers and also demotivating them."99 Evidently, the code of regulations was not always adhered to in matters of discipline, which made it easy for senior public servants to intimidate their juniors.

In addition, it should be noted that executive control of the Public Service was effectuated through the politically established office, the Permanent Secretary, Secretary to the Cabinet and Head of the Public Service. This office was not contemplated by the Independence Constitution, which only provided for the office of Permanent Secretary to the Office of the President. ${ }^{100}$ The office was established under the aforementioned code of regulations, which made it "responsible to the President for the administration of the Public Service."101 In practice, the holder of this office is also the secretary to the cabinet.

A number of laws and regulations were enacted over the last decade to enhance the accountability of the Public Service. These include the Public Officers Ethics Act of 2003,102 the Public Service Commission Regulations of 2005,103 and the Public Procurement and Disposal Act of 2005.104 First, the Public Officers Ethics Act advances the ethics of public officers by providing a code of conduct and ethics, which imposes on public officers a duty of professionalism and prohibits activities such as improper enrichment, conflicts of interest, acting for foreigners, political partisanship, nepotism, and sexual harassment. ${ }^{105}$ It also requires certain public officers to declare their wealth periodically. ${ }^{106}$ Second, the Public Service Commission Regulations establish mechanisms and procedures for the appointment, promotion, and discipline of public servants. ${ }^{107}$ Third, the Public Procurement and Disposal Act aims to ensure that public procurement processes are fair, transparent, and nondiscriminatory. ${ }^{108}$

Despite the existence of these new laws, the executive continued to

99. Id.

100. CONSTITUTION, art. 22(2) (1963) (Kenya).

101. PUb. SERv. COMM'N OF KenYA, CODE of Regulations $\S$ A.7 (2006), available at http://www.publicservice.go.ke/index.php?option=com_docman\&task=cat_view\&gid=122\& Itemid $=386$.

102. Public Officer Ethics Act, (2003) Cap. 183 (Kenya).

103. Pub. Serv. Comm'N Of Kenya, L.N. 28/2005, The Public Service Commission REgULATIONS (2005).

104. Public Procurement and Disposal Act, No. 3 (2005), KEnYa GaZETTE SuPPlement No. 77 .

105. Public Officer Ethics Act, (2003) Cap. $183 \S \S 11-21$ (Kenya).

106. Id. $\S 26$.

107. Pub. Serv. Comm'N of Kenya, L.N. 28/2005, The Public Service Commission REGULATIONS passim (2005).

108. Public Procurement and Disposal Act, No. 3 (2005), KenYa GaZeTte SuPPlement No. $77 \S 2$. 
act with impunity in significant cases. The following examples of abuse of power and corruption illustrate the limitations of the mechanisms of accountability established under the old constitutional order following independence.

Perhaps the most blatant illustration of the abuse of power by the Public Service is the behavior of the head of Public Service and secretary to the cabinet in relation to the 2007 general elections. The Commission of Inquiry into Post-Election Violence established that the National Security Intelligence Service prepared a survey at the direction of the head of Public Service on "the relative positions of the 3 presidential candidates in the polls." 109 Alarmingly, the commission found that "correspondence about the survey appeared to be arranged outside the [national security intelligence] framework."110 Additionally, the Commission established that "on a number of occasions the decision making and behaviour of senior police officers was influenced by factors outside the formal operating arrangements, chain of command and in direct conflict with mandated duties."111 For example, the Commission found that the head of Public Service ordered the Administration Police to train a large number of its officers before polling day so that they could act as agents for the Party of National Unity (under whose banner President Kibaki was seeking reelection) during election polling. ${ }^{112}$ The Commission reports that the "training was conducted by a senior academic, and high ranking government officials including the hierarchy of the Administration Police."113

The Commission also found that the role of these officers "was to disrupt polling and where possible ensure that government supporters amongst the candidates and voters prevailed."114 When the Commission sought an explanation from the head of the Public Service, he responded that the "deployment was approved by the Government and was commissioned for security reasons" and that the "reason for sending those people under plainclothes is that the area was very unfriendly."115 According to the Commission, this "exercise was clandestine in appearance and execution and fell outside the overall elections security command and control arrangements led by the Commissioner of Police."116 Notably, although he was acting in this partisan manner, the

109. WAKI REPORT, supra note 51, at 365-66.

110. Id. at 366 .

111. Id. at 405 .

112. See id. at 405-06.

113. Id. at 406 .

114. Id.

115. Id. (emphasis omitted).

116. Id. 
head of the Public Service had earlier ordered public servants to remain neutral during the elections. ${ }^{117}$ In these circumstances, it is arguable that the head of the Public Service abused the powers of his office.

Whether pursuing regime objectives or engaging in corruption, the typical excuse that government ministers or senior public servants have given is that they are carrying out projects that have been approved by the government. The Goldenberg scandal of the $1990 \mathrm{~s}$-which was a conspiracy by government ministers, senior public servants, and wheeler-dealers to steal public funds-illustrates how the law has typically been violated in the pursuit of such "government-approved projects."

Ostensibly intending to boost the country's foreign exchange reserves by exporting gold and diamonds, a company called Goldenberg International took advantage of the government's export compensation scheme. As required by law, Goldenberg submitted an application to the Minister for Finance for: (1) sole rights to export diamond jewelry and gold out of Kenya for a maximum of ten years; (2) thirty-five percent export compensation on the exports; and (3) approval to establish a financial company to handle its export operations. ${ }^{118}$ In consideration for the grant of these rights, Goldenberg promised that it would remit fifty million dollars annually to the Central Bank of Kenya. ${ }^{119}$ Goldenberg's application was based on the premise that "Kenya has a reasonable supply of diamonds and gold." 120 However, no diamonds are mined locally and the supply of gold is limited. ${ }^{121}$ In addition, the Local Manufacturers (Export Compensation) Act of 1974, which had been enacted to encourage exports, only permitted export compensation on eligible goods ${ }^{122}$ at the rate of twenty percent of the value of the goods exported. ${ }^{123}$ Moreover, such compensation was only due if the goods were physically examined and certified prior to exportation.124 Thereafter, the foreign currency paid for the goods had to be received by an authorized dealer, usually a bank, within ninety days of the date of payment, and the person claiming export compensation was required to

117. James Ratemo, Muthaura Orders Civil Servants to Resign over Politics, E. AFr. STANDARD (Nairobi), Jan. 31, 2007.

118. See REPORT OF THE JUD. COMM'N OF INQUIRY INTO THE GOLDENBERG AFFAIR I 78 (2005) (Kenya), available at http://www.tikenya.org/documents/Goldenberg\%20Report.pdf [hereinafter GOLDENBERG AFFAIR].

119. See id. ๆ 135.

120. Id. I79.

121. Id. \ 80.

122. Eligibility is assessed according to rules of origin contained in the Local Manufacturers (Export Compensation) (Procedures) Regulations made under the Act.

123. GOLDENBERG AFFAIR, supra note 118, $\$ 104$.

124. Id. ๆ 98 . 
provide evidence of such payment. ${ }^{125}$

All of these requirements were violated in the implementation of the Goldenberg scam. First, the Minister for Finance unilaterally approved Goldenberg's application and subsequently failed to stop the project despite a technical evaluation that revealed it was devaluing the Kenyan shilling. ${ }^{126}$ The cabinet did not formally consider, let alone approve, the project. ${ }^{127}$ When later called to account for his action, the Minister for Finance stated that he acted "in pursuance of government policy." 128

Second, the minister approved the payment of compensation at the rate of thirty-five percent of the value of exports and granted a monopoly to Goldenberg, contrary to the provisions of the relevant laws. ${ }^{129}$ Because the law on export compensation only allowed a maximum compensation of twenty percent of the value of exports, the minister approved the payment of the extra fifteen percent to Goldenberg as ex gratia, pending the amendment of the law to formalize the payment of the thirty-five percent export compensation due under the deal with Goldenberg. ${ }^{130}$ Thus the minister gave his approval despite being aware that it was necessary to amend the law before the rate of thirty-five percent compensation could be effected legally. In order to circumvent the law, the extra fifteen percent compensation and the monopoly were instead granted administratively. This extra compensation was then disguised as "customs refunds" in the government's supplementary estimates presented to the legislature. ${ }^{131}$ Not detecting the cover up, the legislature therefore erroneously approved the payment of the extra compensation to Goldenberg.

Third, Goldenberg did not export any diamonds or gold but nonetheless claimed and was paid export compensation at the rate of thirty-five percent. ${ }^{132}$ The law required that the Ministry of Finance had to be satisfied that exports of eligible goods had in fact taken place and that foreign currency had been received for the goods before it could forward the claim to the Commissioner of Customs and Excise for payment of compensation. ${ }^{133}$ With the aid of senior public servants at the Ministry of Finance and the Commissioner of Customs and Excise, Goldenberg was able to falsify records to show that gold and diamond

125. Id.

126. Id. ๆ 105.

127. See id. I 83.

128. Id.

129. Id. I 79.

130. Id. ๆ 104.

131. Id. ๆ 191.

132. Id. ๆ 205.

133. Id. ๆ 128. 
jewelry had been processed and exported, when no such processing or exporting had, in fact, taken place. ${ }^{134}$ Goldenberg then sought and obtained compensation for the nonexistent exports. ${ }^{135}$ Subsequently, it submitted foreign currency, which it had either obtained locally or withdrawn from its overseas accounts, as the proceeds of its exports to the Central Bank. ${ }^{136}$ In this endeavor, Goldenberg was aided by the Central Bank, which granted it a license to deal in foreign currency, despite established regulations, stipulating that only banks could be holders of such licenses. ${ }^{137}$ It is estimated that Kenya lost hundreds of millions of dollars as a result of this scam. ${ }^{138}$

From this account, it is clear that corruption may be the result of abuses of power by government ministers due to the absence of effective accountability mechanisms. In this regard, corruption has been aided by the selective exercise of prosecutorial power. Section 26 of the Independence Constitution vested in the attorney general the power to decide if and when an individual could be prosecuted for a criminal offense. It also gave the attorney general the power to manage criminal proceedings that had been instituted or undertaken by other persons or authorities and to terminate any prosecution. This power was often abused, resulting in individuals being prosecuted, only for charges later to be dropped. In the context of corruption, this power was often applied selectively, with the result that the perpetrators of these crimes were hardly ever punished. ${ }^{139}$ In the Goldenberg Affair, the attorney general chose to institute several cases against the perpetrators of the fraud, instead of instituting a single case, which would have been more efficient as all cases related to the same offenses and the accused persons were the same. ${ }^{140}$ The attorney general consolidated some of the cases, terminated others, and then instituted new ones, creating a "pointless merry go round resulting in serious delay." 141 In light of these circumstances, it is plausible that the selective exercise of the prosecutorial power was "part of an orchestrated cover-up."142 Indeed, none of the cases ever proceeded to a full hearing.

Another significant loophole in the institutional framework was that public servants were not empowered to resist the illegal instructions of their seniors, government ministers, or the President, with the result

134. Id. ๆ 549.

135. $I d$.

136. Id. ๆ 162,178 .

137. Id. \181.

138. See id. ch. $7[\mathrm{~h}]$.

139. See, e.g., WAKI REPORT, supra note 51, at 455-57.

140. See GOLDENBERG AFFAIR, supra note 118, \ 776.

141. Id. 778.

142. Id. ๆ 783 . 
that they often became accomplices to grand corruption schemes. For example, the Government Financial Regulations required public servants to comply with the instructions of ministers, even if the former considered such instructions to be illegal or improper. ${ }^{143}$ Public servants were required to implement the instructions of the minister before registering any objections. These regulations even obliged public servants to implement verbal instructions of ministers, although they could then ask for written confirmation of these instructions..$^{144}$

The practical absence of security of tenure in the Public Service also means that public servants often have no choice but to do the bidding of their seniors, government ministers, and the President. Because they have the power to dismiss or suspend public servants, the President and his ministers are able to intimidate public servants, as demonstrated by the recent resignation of Jacinta Mwatela, the former deputy governor of the Central Bank. By many accounts, Mrs. Mwatela was considered to be "an exemplary public official of uncommon honesty in a very corrupt system." 145 Indeed, she had refused to approve the paperwork for the export compensation claims of Goldenberg. ${ }^{146}$ In the months preceding her resignation in 2008, Mrs. Mwatela, who also served as the chair of the Central Bank's tender committee, refused to approve a tender for the printing of new currency because she believed that it violated the Public Procurement and Disposal Act of 2005. ${ }^{147}$ It appears, however, that the government was intent on awarding the tender and saw Mrs. Mwatela as an obstacle. Accordingly, the President removed her from the Central Bank by appointing her as the permanent secretary of the newly created Ministry of Development of Northern Kenya. ${ }^{48}$ At the same time, the President appointed a new deputy governor for the bank. Thus a career banker was "promoted" to head a ministry of development. At first, Ms. Mwatela declined to take the appointment, contending that it was contrary to the Central Bank of Kenya Act, which she thought gave her security of tenure. ${ }^{149}$ The transfer soon attracted the attention of the public, who thought that she

143. See id. ๆ 591 .

144. E.g., id. $\uparrow 561$ (quoting Ministry of Fin., Government Financial Regulations AND PROCEDURES १ी 5-8 (1989) (Kenya)).

145. Editorial, Mwatela Case Raises Issues of Discipline, DaILY Nation (Nairobi), Sept. 13, 2008, http://www.nation.co.ke/oped/Editorial///440804/470194//ql1h3iz/-/index.html.

146. Robert Shaw, Opinion, Mwatela Deserved Better Treatment, Daily Nation (Nairobi), Sept. 16, 2008, available at http://www.nation.co.ke/oped/Opinion//440808/ 471588/-/3ls9ga/-/index.html.

147. Lucas Barasa, Mwatela Declines New Job and Reports at CBK, DAlly NATION (Nairobi), Sept. 12, 2008, http://www.nation.co.ke/News/-/1056/469718//ttkd6wt/-/index.html.

148. See id.

149. Id. 
was being treated poorly. ${ }^{150}$ The attorney general quickly issued an opinion in which he clarified that like all other public servants, Mrs. Mwatela's continued service as deputy governor could only be at the pleasure of the President. ${ }^{151}$ Further, the attorney general asserted that the Independence Constitution granted security of tenure only to the governor of the Central Bank. At this point, Mrs. Mwatela chose to resign from the Public Service. ${ }^{152}$

It is clear that the attorney general issued an interpretation of the law that suited the interests of the executive perfectly. Shortly thereafter, the Central Bank proceeded with the single-sourced procurement that Mrs. Mwatela had vehemently opposed. ${ }^{153}$ This case demonstrates how public servants attempting to protect the public interest might easily be intimidated into implementing corrupt deals out of fear of losing their position. Furthermore, the procedures and processes established to ensure fair treatment of public servants whenever they are confronted with concerted intimidation tactics or harassment by powerful ministers or senior public servants are either inadequate or ignored in practice. For example, Kenyan courts have held that the head of the Public Service Commission has the power to transfer a public servant from one position to another without due process. ${ }^{154}$ The high court held in one case that a public servant who had been transferred from one position to another because he had "engag[ed] in 'acts of insubordination" had no right to be heard before the transfer became effective. ${ }^{155}$

In addition, public servants are often intimidated into silence. For example, in the Anglo Leasing scam, the head of the Public Service threatened public servants who leaked government documents with punishment under the Official Secrets Act. ${ }^{156}$ In this respect, the Public

150. See, e.g., Opinion, On Mwatela, The AG Should Have Gone By the Public Wish, DAILY NATTON (Nairobi), Sept. 16, 2008, http://www.nation.co.ke/oped/Opinion///440808/ 471578/-/3ls9fe/-/index.html.

151. See Wachira Kang'aru, Law Clear on Removal of Deputy Governor, DaILY NATION (Nairobi), Sept. 16, 2008, http://www.nation.co.ke/News/politics/-/1064/471610/-/ywwlgtz//index.html.

152. David Mugonyi, No Thank You, Mwatela Says, DaILY NATiON (Nairobi), Sept. 16, 2008, http://www.nation.co.ke/News/-/1056/471612///tkt5h5/-/index.html.

153. Jaindi Kisero, De La Rue Gets Another Currency Deal Without Rival Bids, DAILY NATION (Nairobi), July 18, 2009, http://www.nation.co.ke/News/-/1056/626170/-/item/0//y9oxv2/-/index.html.

154. See Republic v. The Permanent Sec'y/Sec'y to the Cabinet and Head of Pub. Serv. Office of the President and the Permanent Sec'y, (2006) e.K.L.R. 1, 3 (H.C.K.) (Kenya).

155. Id.

156. Gladwell Otieno, The NARC's Anti-Corruption Drive in Kenya, 14 AFr. SECURITY REV., no. 4, 2005, at 69, 75-76 (describing another government procurement scandal, this 
Officer Ethics Act is proving to be a double-edged sword. While its declared purpose is to advance the ethics of public officers, it may aid corruption because senior public servants often use its provisions to intimidate their subordinates into silence. Among other things, the Act provides that "[a] person who, without lawful excuse, divulges information acquired in the course of acting under this Act is guilty of an offence and is liable, on conviction, to a fine not exceeding five million shillings or to imprisonment for a term not exceeding five years or to both."157 In the context of the Mwatela case, for example, the governor of the Central Bank invited the police to investigate the leakage of information from the bank. ${ }^{158}$

\section{B. Organization, Exercise, and Accountability of Legislative Power}

While it is arguable that the legislature is becoming an institution of "genuine . . countervailing power," 159 there are definite concerns that it is not sufficiently accountable, especially in the manner in which legislators have exercised their "collective powers" of policy making, legislating, and overseeing the executive branch. As examined below, the absence of effective accountability mechanisms in the legislature has produced two undesirable results. First, legislators are vulnerable to influence from special interest groups, which jeopardizes the ability of the legislature to safeguard the public interest. Second, the legislature's ability to hold the executive accountable is questionable because its committees, which form a critical part of its arsenal of oversight instruments, often consist of legislators against whom credible allegations of corruption have been made, and who cannot therefore be expected to be genuine champions of the public interest.

At the time of independence, the legislature had two chambers, a House of Representatives and a Senate. The bicameral legislature was part of a federalist system, created by political parties representing minority ethnic groups that thought such a structure would protect their interests. ${ }^{160}$ However, the federal system was not sustained. Once the Kenya African National Union (KANU) party, which represented

time involving a contract with Anglo Leasing and Finance Ltd. for passport issuing equipment).

157. Public Officer Ethics Act, (2003) Cap. $183 \S 41$ (Kenya).

158. Samwel Kumba, Kenya: CBK Probes Key Data Leakage, CitTzEN (Dar es Salaam), Sept. 26, 2008, available at http://allafrica.com/stories/printable/200809260431.html.

159. Joel D. Barkan \& Fred Matiangi, Kenya's Tortuous Path to Successful Legislative Development, in Legislative Power in Emerging African Democracies 33, 33 (Joel D. Barkan ed., 2009).

160. See Stephen N. Ndegwa, Citizenship and Ethnicity: An Examination of Two Transition Moments in Kenyan Politics, 91 AM. POL. ScI. REV. 599, 613 (1997). 
the interests of the majority ethnic groups, assumed power, it undermined and then abolished the federal system and bicameral legislature. On the one hand, the KANU government withheld funds from the regional governments, which soon lost their viability. ${ }^{161}$ Such machinations frustrated the Kenya African Democratic Union (KADU), the opposition party representing minority interests, which then decided to disband and join the ruling party in 1964. Kenya thus became a de facto one-party state. ${ }^{162}$ On the other hand, the bicameral legislature was terminated by a constitutional amendment in 1966 that merged the two chambers into a National Assembly. ${ }^{163}$ Today, the National Assembly consists of 210 elected members, twelve nominated members, and two ex officio members, namely the speaker of the assembly and the attorney general.

The independence of the legislature was further undermined by a series of constitutional amendments, the effect of which was to consolidate power in the presidency. Some of these amendments gave the President the power to suspend the proceedings of or dissolve the legislature. ${ }^{164}$ The legislature therefore had no control of its calendar, and the President could simply terminate its proceedings whenever he felt that the legislature was going off course. Additionally, the absence of political party competition enabled the President to control the appointment of the presiding officer, or speaker, of the legislature. Only individuals who were considered to be loyal to the President could be elected to the office of speaker, which played a pivotal role in facilitating the agenda of the executive in the legislature. ${ }^{165}$

Therefore, the legislature became a mere appendage of the executive that was administered through the office of the President. For example, the bureaucracy of the legislature was part of the public service. Hence the public service recruited personnel for the legislature's bureaucracy and regulated its terms and conditions of service. The committee system of this legislature was also rudimentary and it therefore had little capacity to hold the executive accountable. ${ }^{166}$ Nor did it have sufficient

161. Id. at 606 .

162. David M. Anderson, 'Yours in Struggle for Majimbo'. Nationalism and the Party Politics of Decolonization in Kenya, 1955-64, 40 J. CONTEMP. HIST. 547, 547 (2005) (explaining why KADU disbanded and joined KANU).

163. ConstiTUTION, art. 30 (1963) (Kenya). The Constitution of Kenya (Amendment) Act, No. 40 of 1966 .

164. Constitution, art. 59(1), (2) (1963) (Kenya).

165. See Barkan \& Matiangi, supra note 159, at 40 (explaining how one of the mechanisms used by African presidents to control the assembly was by "control[ling] the appointment and approach of its chief presiding officer, the Speaker.").

166. See id. at 37 (revealing that in actuality the legislature was dependent on the executive to assign it many of its resources). 
funds, as the Ministry of Finance ensured that it was starved of funds when determining its budget. ${ }^{167}$ In addition, legislators were poorly paid and depended on executive patronage for their political survival. For example, those who were deemed loyal were appointed as ministers, assistant ministers, or chairmen of public corporations. Further, the President often gave legislators cash handouts to enable them to meet the demands of their constituents. Due to these constraints, the legislature played only a minimal role in policy making and legislation, even if it provided a useful forum for the ventilation of issues of national concern.

Nevertheless, the return to multiparty politics in the 1990s facilitated the growth of the legislature's independence by, among other things, creating a political environment in which the legislature's reform could be meaningfully deliberated. It was not until 2000 that the independence of the legislature was guaranteed, following an amendment to the constitution that unlinked the legislature from the executive by establishing a parliamentary service to oversee the legislature's administrative affairs. ${ }^{168}$ The enactment of a statutory law further facilitated the implementation of this amendment. ${ }^{169}$ In addition, these reforms sought to dilute the powers of the speaker by creating a Parliamentary Service Commission (PaSC). ${ }^{170}$ The legislators also enacted laws which improved their remuneration and terms of service exponentially. ${ }^{171}$ Indeed, their emoluments are now the highest on the continent. ${ }^{172}$ Presumably, their new salaries should have freed them from the financial dependency on the executive that had hampered their effectiveness during the single-party era.

The Parliamentary Service consists of a clerk of the National Assembly and other officers appointed by the PaSC. ${ }^{173}$ The clerk is the chief executive of the Parliamentary Service, and is responsible for matters of day-to-day administration. ${ }^{174}$ Another key function of the clerk is to advise members of the legislature on parliamentary procedure and practice. ${ }^{175}$ The clerk is accountable to the PaSC, and can be suspended or removed from office "at any time and in such manner as may be prescribed under [the Parliamentary Service] Act ... for

167. See id. (recounting that for nearly fifty years the assembly was understaffed to a point that it did not have its own legal draftsperson).

168. Constitution of Kenya (Amendment) Act, No. 3 of 1999.

169. Parliamentary Service Act, (2000) Cap. 185 (Kenya).

170. Constitution, art. 45B (1963) (Kenya).

171. National Assembly Remuneration (Amendment) Act, No. 2 of 2003 (Kenya).

172. Barkan \& Matiangi, supra note 159 , at 55-57.

173. Constitution, arts. 45A, 45B (1963) (Kenya).

174. Parliamentary Service Act, (2000) Cap. $185 \S 13$ (Kenya).

175. Id. $\S 14$. 
inability to perform the functions of his office (whether arising from infirmity of body or mind or from any other cause) or for misbehaviour." 176

On the other hand, the PaSC consists of the speaker of the legislature (who is the chairman), a vice chairman, the leader of government business in the legislature, the leader of the opposition party with the highest number of seats in the legislature, and seven members appointed by the legislature from among its members. ${ }^{177}$ of the seven ordinary members, four are nominated by the parliamentary party (or parties) forming the government, while the other three are nominated by the parliamentary parties forming the opposition. ${ }^{178}$ The vice chairman is elected by the PaSC from the lot of these ordinary members. ${ }^{179}$ Upon the dissolution of the legislature, all the members of the PaSC remain in office until new members are appointed by the next legislature. ${ }^{180}$ The powers of the PaSC include constituting and abolishing offices in the Parliamentary Service and directing and supervising the administration of the Service.181 As for accountability, the PaSC answers to the legislature; for example, it is required to submit annual audits of its expenditures to the legislature. ${ }^{182}$ Furthermore, it is required to annually prepare and present to the legislature a report of its operations. ${ }^{183}$

The speaker also presides over the legislature and is elected by legislators in accordance with its rules of procedure, also known as "standing orders." 184 The speaker is assisted by a deputy, who is also elected by the members of the legislature. In keeping with the traditions of the Westminster system, the speaker is the spokesperson or representative of the legislature. 185 Subject to the provisions of the standing orders, the speaker wields considerable power with respect to influencing the agenda and deliberations of the legislature. For example, the speaker determines who contributes to deliberations, closes debate and determines when matters should be put to vote, and punishes members who do not adhere to the established rules of debate

176. $I d . \S 16$.

177. CONSTITUTION, art. 45B(1) (1963) (Kenya).

178. $I d$. art. $45 \mathrm{~B}(1)(\mathrm{e})$.

179. Id. art. $45 \mathrm{~B}(1)(\mathrm{b})$.

180. Id. art. $45 \mathrm{~B}(2)(\mathrm{a})$.

181. Id. art. $45 \mathrm{~B}(5)(\mathrm{a})$, (d)

182. Id. art. $45 \mathrm{~B}(5)(\mathrm{e})(\mathrm{ii})$.

183. Parliamentary Service Act, (2000) Cap. $185 \S 25$ (Kenya).

184. ConstTTUTION, art. 37 (1963) (Kenya).

185. See Marcelo Jenny \& Wolfgang C. Müller, Presidents of Parliament: Neutral Chairmen or Assets of the Majority?, in PARLIAMENTS AND MAJORITY RULE IN WESTERN EUROPE 326, 330 (Herbert Döring ed., 1995). 
and parliamentary behavior. ${ }^{186}$ In exercising these powers, the speaker should ensure that he or she does not "hinder the legitimate expression of all shades of opinion while at the same time ensuring that parliamentary debates run smoothly." 187 In addition, the speaker has the power to interpret the standing orders and other regulations governing the functioning of the legislature. Where the standing orders do not resolve a matter in question, the speaker has the power to resolve such matters ${ }^{188}$ and may be guided by the precedents of the legislature.

The speaker and the deputy speaker both answer to the legislature and can be removed from office by a resolution supported by the votes of at least seventy-five percent of all members of the legislature. ${ }^{189}$ Although this may seem to be a high threshold, the record of the legislature demonstrates that legislators would be able to obtain the necessary votes if they deemed it to be in their best interest to get rid of the speaker. Thus the fact that legislators can dismiss the speaker limits the ability of the speaker to regulate the manner in which the legislators exercise their collective power to make policies, laws, and hold the executive to account. In these circumstances, the speaker will be mindful of the fact that he or she can be removed from office by legislators. The speaker is only an ex officio member of the legislature. Once elected, the speaker will likely want to be in the good graces of the legislators. While presiding officers in other democracies are also elected by legislators, the vulnerability of the speaker to the whims of legislators requires the creation of auxiliary mechanisms to facilitate the accountability of the exercise of the legislature.

Since the relevant laws regarding removal of the speaker and clerk have not circumscribed how these wide powers of dismissal are supposed to be exercised, they remain subject to abuse and may serve to make the speaker and the clerk subservient to the legislature and the $\mathrm{PaSC}$, respectively. In the case of the $\mathrm{PaSC}$, it is worth noting that it has a short-term perspective, given that each legislature only has a shelf life of five years. ${ }^{190}$ Because it wields immense power over the clerk, the PaSC arguably may prevail upon the clerk to make decisions that only serve the short-term objectives of legislators. In these circumstances, it is doubtful whether, for example, the legislature can objectively debate audits of the accounts of the PaSC.

186. Republic of Kenya National Assembly, Standing Orders, (2008) §§ 47(3), 53(1)-(2), 75(4), 97(2).

187. Georges Bergougnous, Presiding Officers of National Parliamentary ASSEMBLIES: A WORLD COMPARATIVE STUDY 74 (1997).

188. Republic of Kenya National Assembly, Standing Orders, (2008) § 1.

189. ConstituTION, arts. 37(2)(c), 38(3)(d) (1963) (Kenya).

190. ConstiTUTION, art. 59(4) (1963) (Kenya). 
A different picture of the democratic character of the legislature also emerges when one examines how legislators exercise their collective power to make policies, laws, and to hold the executive accountable. This power is exercised through debate and voting in plenary sessions of the legislature. Its exercise is facilitated by the establishment of committees, which constitute a mechanism for providing legislators with the information they need to implement decisions. The committee system enables the legislature to organize its affairs and to shadow the operations of government ministries, departments, and agencies. ${ }^{191}$ Thus the business of the legislature is primarily conducted in, or through, the committees. With respect to holding the executive accountable on a daily basis, the work of the legislature revolves around the so-called departmental committees, which investigate the activities and administration of the government ministries, departments, and agencies assigned to them. ${ }^{192}$ At present, there are twelve such committees. ${ }^{193}$ Their functions are to investigate and report on the activities and administration of the assigned ministries and departments, to study and review legislation referred to them, and to recommend proposed legislation. ${ }^{194}$

Other critical committees are the Public Accounts Committee and the Public Investments Committee, which investigate the expenditures of government ministries and departments. ${ }^{195}$ Both have the power to examine public accounts and the reports of the controller and auditor general.196 These committees have been given significant powers to enable them to carry out their functions, including the power to summon individuals to appear before them. ${ }^{197}$ The committees are constituted according to the distribution of seats among the political parties represented in the legislature. ${ }^{198}$ While the majority party also has the majority of seats in the committees, in practice the chairperson

191. See Barkan \& Matiangi, supra note 159 , at $48-49$.

192. Republic of Kenya National Assembly, Standing Orders, (2008) § 198(3).

193. These are the committees on (1) Administration and National Security; (2) Agriculture, Livestock and Cooperatives; (3) Defence and Foreign Relations; (4) Education, Research and Technology; (5) Energy, Communication and Information; (6) Finance, Planning and Trade; (7) Health; (8) Justice and Legal Affairs; (9) Labour and Social Welfare; (10) Lands and Natural Resources; (11) Local Authorities; and (12) Transport, Public Works and Housing. Id. sched. 2.

194. Id. $\$ 198(3)$.

195. Barkan \& Matiangi, supra note 159 , at 49.

196. Id.

197. Republic of Kenya National Assembly, Standing Orders, (2008) §173.

198. Republic of Kenya National Assembly, Standing Orders, (2008) $\S \S 187(2)-(3)$, $188(2)-(3)$. 
of the committee is chosen from an opposition party. ${ }^{199}$ For example, the head of the official opposition party usually chairs the important Public Accounts Committee. ${ }^{200}$ While this practice enhances the impartiality and legitimacy of the work of the committees, it should be noted that political parties typically use appointments to committees to reward loyalty, which means that committees will not necessarily consist of the most competent legislators. ${ }^{201}$

How, then, have legislators exercised their powers to make policies and laws, and hold the executive to account? In the recent past, the legislature has arguably been unduly influenced by special interest groups in exercising its lawmaking power, as the enactment of the Tobacco Control Act of 2007 illustrates. ${ }^{202}$ Furthermore, the legislature has not only enacted unconstitutional laws (such as the Constituency Development Fund Act), ${ }^{203}$ but has also failed to amend laws that have been declared unconstitutional (such as the Kenya Roads Board Act). ${ }^{204}$ These examples demonstrate that the legislature is not only prone to the undue influence of special interest groups, but may also be abusing its collective power.

While it is to be expected that different interest groups will legitimately lobby the legislature to enact favorable policies and laws, there should be mechanisms to ensure that interest groups seeking specific legislative outcomes do not subvert the public interest. Such mechanisms include those that regulate lobbying, conflicts of interest, misconduct, and even corruption in the legislature. In Kenya, an attempt has been made to establish such mechanisms, as exemplified by the National Assembly (Powers and Privileges) Act. ${ }^{205}$ The primary purpose of the Act is to codify the convention of parliamentary privilege, which guarantees legislators the independence and freedom of speech necessary to effectively perform their duties of "honest, unbiased and impartial examination and inquiry and criticism." 206 Thus, according to this Act, "[n]o civil or criminal proceedings shall be instituted against any member for words spoken before, or written in a report to, the

\footnotetext{
199. World Bank, Understanding the Evolving Role of the Kenya National Assembly in Economic Governance in Kenya: An Assessment of Opportunities for Building Capacity of the Tenth Parliament and Beyond, If 78, Report No. 45924-KE (May 2008) (on file with author).

200. Id.

201. Id. ๆ 96.

202. Tobacco Control Act, No. 4 (2007) (Kenya).

203. Constituencies Development Fund Act, (2003) Cap. 10 (Kenya).

204. Kenya Roads Board Act, (1999) Cap. 408.

205. The National Assembly (Powers and Privileges) Act, (1952) Cap. 6 (Kenya).

206. Graham Zellick, Bribery of Members of Parliament and the Criminal Law, 1979 PUB. LaW 31, 43.
} 
Assembly or a committee, or by reason of any matter or thing brought by him therein by petition, Bill, resolution, motion or otherwise."207 Because these privileges can be abused, the Act also empowers the speaker to "issue directions in the form of a Code of Conduct regulating the conduct of members of the Assembly whilst within the precincts of the Assembly other than the Chamber."208 These powers of the speaker are exercised through the Committee of Privileges, which is empowered to inquire into allegations of breaches of the Code of Conduct. ${ }^{209}$ The conduct of legislators within the debating chamber is also regulated by the standing orders. ${ }^{210}$

In general, the conduct of legislators outside the debating chamber or the precincts of the legislature is not regulated. In particular, the absence of proper regulation has meant that legislators can serve on committees "even though their membership would entail a conflict of interest-either because they face allegations of corruption, are allegedly allied to corruption cartels, or have commercial interests that are overseen by these committees." 211 It should be noted, however, that the legislature's new standing orders now provide that when an adverse recommendation has been made against a legislator in a committee report that has been adopted by the House, that legislator is ineligible for election as chairperson or vice chairperson of any committee. ${ }^{212}$ This is the context in which the Tobacco Control Act was enacted. Since the late 1990 s, the Kenyan government has attempted to regulate the sale, marketing, and consumption of tobacco products, with the aim of implementing the World Health Organization's Framework Convention on Tobacco Control. ${ }^{213}$ However, tobacco companies saw these attempts as a threat to the profitability of their businesses and therefore lobbied against the enactment of any adverse legislation. ${ }^{214} \mathrm{~A}$ bill introduced in the legislature in 1999 did not make any progress until 2004, thanks in large part to the resistance of the tobacco lobby. ${ }^{215}$ When the bill was reintroduced in the legislature in 2004, the tobacco lobby organized a

207. The National Assembly (Powers and Privileges) Act, (1952) Cap. $6 \S 4$ (Kenya).

208. Id. $\S 9$ (emphasis added).

209. Id. § 10(4).

210. See Republic of Kenya National Assembly, Standing Orders, (2008) § 97.

211. World Bank, supra note 199, ๆ 81.

212. Republic of Kenya National Assembly, Standing Orders, (2008) § 162(2).

213. Preeti Patel et al., "The Law Was Actually Drafted by Us but the Government Is to Be Congratulated on Its Wise Actions": British American Tobacco and Public Policy in Kenya, 16 TOBACCo CoNTROL e1, e2 (2007).

214. Ngumbao Kithi, MPs Mix Tobacco Bill Talks with Pleasure, DaILY NaTion (Nairobi), Nov. 22, 2004.

215. See Dagi Kimanike, New Anti-Tobacco Bill to Hit Industry Hard, EAST AFRICAN (Nairobi), Oct. 5, 1999. 
retreat for more than forty legislators at which it prevailed upon them to make certain desired changes to the bill. ${ }^{216}$ Reports revealed that the legislators were each flown to the beach resort that served as the venue for this meeting, accommodated, and entertained at the expense of the tobacco lobby.217 While the tobacco lobby was perfectly entitled to seek favorable legislation, this retreat arguably undermined the ability of the legislators to act free of undue influence. In addition, the retreat privileged the interests of the tobacco lobby at the expense of other groups in society who do not have equivalent resources to entertain legislators. Further, it undermined public confidence in the legislature.

The Kenyan public perceives the legislature as one of the most corrupt public institutions. ${ }^{218}$ Indeed, there is a growing perception that legislators do not serve the public interest and are only motivated by selfish interests. ${ }^{219}$ There are even allegations that legislators have taken bribes from wealthy politicians to influence the deliberations and decisions of the legislature. ${ }^{220}$ Therefore, it does not seem that salary increases have necessarily enhanced the independence of legislators. Additionally, the legislature has been the recipient of capacity-building initiatives (including enhancing legislators' understanding of technical issues) that have led to lobbying. For example, the legislature has established an informal forum, labeled the Parliamentary Initiatives Network, to facilitate its interactions with various nongovernmental organizations that support the work of the legislature. ${ }^{221}$ Unfortunately, the criteria for membership of, or the rules of engagement in, this forum are not clear; the result is that it may be perceived as an instrument for

216. Tom Mosoba \& Caroline Mango, MPs Vow to Amend Tobacco Bill Clauses, STANDARD (Nairobi), Nov. 20, 2004, available at http://allafrica.com/stories/200411220 372.html.

217. Mark Agutu, Queries on Lobbying and Retreats, DaILY NATION (Nairobi), Dec. 19, 2004, available at http://allafrica.com/stories/200412200679.html.

218. See, e.g., Cyrus Kinyungu, MPs Are Most Corrupt, STANDard (Nairobi), Dec. 6, 2006, available at http://allafrica.com/stories/200612061243.html; Mugo Njeru, MPs in 'Most Corrupt' League, DAILY NATION, Dec. 10, 2005, available at http://allafrica.com/stories/200512100099.html.

219. See, e.g., Martin Mutua \& Andrew Teyie, Shame: MPs for Hire, STANDARD (Nairobi), Nov. 18, 2004, available at http://allafrica.com/stories/200411180875.html; Njeri Rugene, Bribery Rampant in Kenya's Parliament, SundaY NATION (Nairobi), May 16, 2009, available at http://africanewsonline.blogspot.com/2009/05/bribery-rampantinkenyas-parliament.html; Editorial, Put the Voters' Interests First, DAIIY NATION (Nairobi), Nov. 21, 2004, available at http://allafrica.com/stories/200411220395.html.

220. Rugene, supra note 219.

221. The members of the forum are SUNY-Kenya, Institute of Economic Affairs, International Commission of Jurists-Kenya, Law Society of Kenya, Centre for Governance \& Development, International Federation of Women Lawyers, Institute for Education in Democracy, Transparency International-Kenya, African Youth Trust, African Centre for Open Governance, and PLATO Institute. 
special interest groups to promote their agenda in the legislature.

Let us now examine how the legislature has exercised its collective power with respect to the enactment of the Constituency Development Fund Act (CDF) and the Kenya Roads Board Act.

It should be noted at the outset that the CDF has noble objectives as it seeks to enhance the participation of citizens in the initiation and implementation of development projects at the local level. The problem is that the CDF violates the separation of powers doctrine in a number of respects. In particular, it gives individual legislators the executive power to expend public resources and expects that they will account to the legislature for such expenditures. Two principal institutions of the CDF are important in this respect, namely the Constituency Development Committee (CDC) and the Constituency Fund Committee (CFC). ${ }^{222}$ The CDC is arguably the most critical organ of the CDF; the idea of devolution ${ }^{223}$ that informs the CDF initiative would not be realized without it. Its main function is to deliberate projects proposed from all the locations (or districts) of the constituency and then determine which projects should be given priority. ${ }^{224}$ The CDF requires the establishment of a CDC in every constituency. ${ }^{225}$ This critical organ, whose functions are executive in nature, is constituted, convened, and chaired by a member of parliament. ${ }^{226}$ While the CDF attempts to regulate what kind of persons can serve as members of the CDC, the chair ultimately has the prerogative to appoint members of his or her choosing. ${ }^{227}$ In addition, the CDF gives legislators the power to identify the projects which are to be funded by the $\mathrm{CDF},{ }^{228}$ therefore making the legislator a grand political patron at the local level.

The CFC functions as an oversight body. It is established as a select committee of the legislature and consists of "a chairman and not more than ten other [legislators] who are not Ministers or Assistant Ministers of Government."229 Its functions include overseeing the policy framework, the legislative framework, and the implementation of the CDF. ${ }^{230}$ Legislators audit their own work under the CDF and answer to themselves through the CFC.

In practice, legislators have not always been transparent in exercising their powers under the CDF. Additionally, districts opposed

222. Constituencies Development Fund Act, (2003) Cap. 10 § 23, 27 (Kenya).

223. Id. § 23(4).

224. See id.

225. Id. § $23(1)$.

226. Id.

227. Id.

228. Id. $\S 12(1)$.

229. Id. § 27(1).

230. Id. $\S 27(4)(\mathrm{d}),(\mathrm{e})$ 
to the legislators tend to be bypassed and therefore may not benefit from the funds. ${ }^{231}$ Subsequently, the CDF may therefore be enhancing subethnic, regional, and class differences. ${ }^{232}$ Cases of misappropriation of funds and poor implementation of projects have also been reported, ${ }^{233}$ proving that it is unrealistic to expect that legislators will objectively oversee their own actions. The limitations of the CDF are perhaps best captured by a commentator, writing that " $[t]$ he scenario presented by the Act whereby the legislator makes a law . . . , participates in implementing the law ... and then accounts for the expenditure to Parliament (in this case to himself) throws democratic accountability overboard."234

The judiciary had occasion to review the CDF in the case of Oyoo $v$. Syongo, where the applicants complained of inequitable distribution of the funds allocated to the Gwasi Constituency. ${ }^{235}$ The court noted that "there is no clear mechanism in the Act to control abuse or excessive use of authority by the sitting member of [P]arliament under the powers given to him under section 23 of [t]he Act." ${ }^{236}$ In response to public outcry, the legislature made some changes to the CDF in 2007, but these changes do not address concerns about the separation of powers and do not significantly alter the provisions of the CDF. ${ }^{237}$

The Kenya Roads Board Act (Roads Act) provides the second illustration. It establishes a board to oversee the maintenance, rehabilitation, and development of the nation's roads.238 More specifically for present purposes, the Roads Act establishes a Constituency Roads Committee (CRC) for every district.239 The Roads Act incorporated all the legislators from the district members into this government agency. ${ }^{240}$ Shortly after this law was enacted, a citizen challenged its constitutionality in the case of Republic v. Kenya Roads Board. ${ }^{241}$ In this case, the applicant asked the court to stop the implementation of the Roads Act, and to declare it unconstitutional because it gave legislators the power to both enact and enforce law. ${ }^{242}$

231. Kenya Private Sector alliance, Workshop Report on the Constituency DEVELOPMENT FUND 4-5 (2006) (on file with author).

232. Id.

233. Id.

234. Id. at 22.

235. Oyoo v. Syongo, (2005) e.K.L.R. 1, 3 (H.C.K.) (Kenya).

236. Id. at 5.

237. Constituency Development Fund (Amendment) Act, (2007) (Kenya).

238. Kenya Roads Board Act, (1999) Cap. $408 \S 6(1)$.

239. Id. $\S 17(1)$.

240. See id. $\$ 17(2)(b)$.

241. See Republic v. Kenya Roads Board, (2001) e.K.L.R. (H.C.K.) (Kenya).

242. Id. at 2 . 
The court agreed, observing that "it would be against the constitutional principle of separation of powers for [legislators] to take part in actual spending, then submit their annual estimates to themselves in [P] arliament for approval, then query the spending themselves through the Public Accounts Committee or the Public Investment Committee."243 However, the legislature was unmoved and this illegality still persists to date. The failure to amend such laws may be contributing to public perceptions that legislators are greedy, selfish, and unruly. ${ }^{244}$

Based on the foregoing account, it is clear that the legislature often exercises its power in an arbitrary manner. This is in part because the legal order does not circumscribe the power of legislators to dismiss the speaker, the power of the PaSC to dismiss the clerk, or the collective power of the legislators. As a result, the legislature is becoming increasingly unaccountable for the exercise of its powers.

\section{Organization, Exercise, and Accountability of Judicial Power}

Unlike the legislature, which has gained considerable autonomy from the executive, the judiciary remains vulnerable to manipulation. At the same time, the Chief Justice, who is the head of the judiciary, enjoys immense power. The powers of the President and the Chief Justice have been exercised in ways that undermine the institutional autonomy of the judiciary and the decisional independence of judicial officers, respectively. As a result, judicial officers are not only insecure in their positions, but may also become enablers of corruption, as the decision of the High Court in Republic v. Judicial Commission of Inquiry into the Goldenberg Affair ex parte George Saitoti (Saitoti) demonstrates. ${ }^{245}$

The constitutional amendments of the 1960s, which sought to enhance the powers of the President, weakened the judiciary. On the basis that an impartial and independent judiciary would be required if the rule of law were to thrive in Kenya, section 184 of the Independence Constitution established a Judicial Service Commission (JSC) to regulate matters such as judicial appointments and disciplinary actions. The membership of the JSC is comprised of the Chief Justice (as

243. Id. at $30-31$.

244. See Marc Lacey, Kenyan Parliament Unites, for More Money, N.Y. TIMEs (May 22, 2006), http://www.nytimes.com/2006/05/22/world/africa/22iht-kenya.html?_r=1\&pagewanted=all.

245. See Republic v. Judicial Comm'n of Inquiry into the Goldenberg Affair, (2006) e.K.L.R. 1, 3.4 (H.C.K.) (Kenya) (noting, in the recitation of the errors of fact, the unfairness that would have been served had the original decision of the commission stood). 
chairman), two judges nominated by the governor-general (acting in consultation with the Chief Justice), and two members of the PSC nominated by the governor-general acting in consultation with the chairman of the PSC. Under section 172 of this constitution, the Chief Justice is appointed by the governor-general, acting in accordance with the advice of the prime minister, while other judges were appointed by the governor-general acting in accordance with the advice of the JSC. Judges could only be removed from office for inability to perform functions or misbehavior, a determination made by an impartial tribunal appointed by the governor-general with the possibility of appeal to the Judicial Committee of the Privy Council in England, whose decision the governor-general would act upon. ${ }^{246}$ The JSC was also given the power to appoint other judicial officers, such as magistrates.

Following the constitutional amendments, the power to appoint the Chief Justice was transferred to the President, who was no longer required to consult with anyone. ${ }^{247}$ In addition, while the President was now required to consult the JSC in appointing judges, little if any consultation occurred in practice. ${ }^{248}$ The President then appointed all the members of the JSC-the Chief Justice (who is the chairman), the attorney general, two judges (one from the High Court and the other from the Court of Appeal), and the chairman of the PSC. ${ }^{249}$ The functions of the JSC were to appoint, discipline, and dismiss magistrates, the registrar or deputy registrar of the High Court (who are also the main administrative officers), and all other paralegal officers. ${ }^{250}$ In practice, however, the JSC delegated all these powers to the Chief Justice. 251

The system for appointing judges was open to abuse because it established no standards or criteria for vetting candidates. A task force established to examine the question of judicial reform noted that " $[t]$ he process through which candidates for appointment are currently identified and vetted by the JSC is neither transparent, nor based on any publicly known or measurable criteria" and is certainly not

246. G. Kamau Kuria and J.B. Ojwang, Judges and the Rule of Law in the Framework of Politics: The Kenya Case, 1979 PUB. L. 254, 267.

247. CONSTITUTION, art. 61(1) (1963) (Kenya).

248. Id. art. 61(2).

249. Id. art. 68(1).

250. Id. art. 69.

251. Interview with judges, in Nairobi, Kenya (Aug. 2009) [hereinafter Nairobi Interview]. 
competitive. ${ }^{252}$ Accordingly, the individuals who have become judicial officers have not necessarily been the most deserving. Even lawyers with disciplinary proceedings pending before the Law Society have been appointed as judges. Arguably, such judicial officers are likely to perceive it to be in their best interest to protect the interests, and even misdeeds, of the appointing authority. Furthermore, section 61 of the Independence Constitution (as amended) gave the President the power to appoint judges in an acting capacity. Again, this power enabled the executive to control the judiciary to the detriment of judicial independence, proving that judges were not insulated from external influences.

With respect to the removal of judges, section 62 of the Independence Constitution provided that the Chief Justice and other judges could be dismissed by the President-for inability to perform the functions of their office or for misbehavior-if an impartial tribunal recommended their removal. Unfortunately, it failed to establish due process mechanisms to ensure that the process of removal-including the exercise of the power to recommend the establishment of a tribunal-was transparent, impartial, and fair. In these circumstances, the threat of removal then operated as the proverbial sword of Damocles, in the sense that judicial officers never knew when it might strike. ${ }^{253}$

In addition, it should be noted that the Chief Justice wielded immense power that could threaten the decisional independence of judges. For a long time, the judiciary was treated as a branch of the Public Service. This status changed in the early 1990s when the judiciary was unlinked from the Public Service and placed under the charge of the Chief Justice, thereby enhancing his power. As the head of the judiciary, the Chief Justice possessed wide-ranging but unregulated powers, including determining which judges heard what cases and where litigants could file their cases, supervising and disciplining judicial officers, allocating office space and housing, transporting judicial officers, transferring judicial officers from one geographic station to another, and initiating the process of removing judges. ${ }^{254}$ Because the exercise of these powers was not circumscribed, they could

\footnotetext{
252. FinAL REPORT of the TASK ForCe ON JUD. REFoRMS 24 (2010), available at http://www.kenyalaw.org/Downloads/Final Report of the Task Force on Judicial Reforms.pdf [hereinafter JUDICIAL REFORM REPORT].

253. Thus the International Commission of Jurists observes that "[t]he possibility that they could be next in line to be publicly castigated and removed from office without due process has lowered the general esprit de corps of the judiciary as a whole." INT'L COMM'N OF JURISTS [ICJ], KENYA: JUDICIAL INDEPENDENCE, CORRUPTION AND REFORM 16 (2005).

254. See, e.g., JUDICIAL REFORM REPORT, supra note 252, at 61-62.
} 
be abused to the detriment of judicial independence and accountability. Thus, judges confronted with these powers may have been inclined to do the bidding of the Chief Justice.

In addition, the arbitrary powers of the Chief Justice were enhanced by the Public Officer Ethics Act. ${ }^{255}$ Section 5 of the Act requires public institutions to establish codes of conduct and ethics. In the case of the judiciary, rule 4 of the Judicial Service Code of Conduct and Ethics established under the Act requires judicial officers "having information establishing a likelihood that another judicial officer has violated this Code or reflecting the other judicial officer's lack of fitness to hold judicial office shall inform the Chief Justice." ${ }^{256}$ Rule 14(1) of the Code also prohibits judicial officers from making "public statements on matters affecting Government programmes or policies of the Judicial Service without the specific authority of the Chief Justice." Yet the Code fails to specify how the Chief Justice should act when a judicial officer violates it. Arguably, it therefore gives the Chief Justice an additional instrument with which to intimidate judicial officers.

The so-called "radical surgery" 257 of the judiciary that saw the suspension, and then dismissal, of some twenty judges on allegations of corruption in 2003 provides a good example of how the Chief Justice exercises his immense powers. In response to allegations of corruption in the judiciary, the new Chief Justice appointed an Integrity and AntiCorruption Committee, which was to be headed by Justice Aaron Ringera, then judge of the High Court. ${ }^{258}$ The Ringera Committee's mandate was to

(i) investigate and report on the magnitude of corruption in the Judiciary;

(ii) identify the nature, forms and causes of corruption;

(iii) find out the level of bribery in monetary terms;

(iv) report on the impact of corruption in the performance of the Judiciary;

255. Public Officer Ethics Act, (2003) Cap. 183 (Kenya).

256. Jud. Serv. Comm'N, L.N. 50/2003, Judictal Service Code of Conduct AND ETHICS (2005) (Kenya).

257. ICJ, supra note 253 , at 20.

258. REPORT OF THE INTEGRITY AND ANTI-CORRUPTION COMM. OF THE JUDICIARY OF KENYA, at I (2003), available at http://www.marsgroupkenya.org/Reports/Government/ Ringera_Report.pdf. 
(v) identify corrupt members of the Judiciary and recommend disciplinary or other measures against them;

(vi) recommend strategies for the detention and prevention of corruption in the Judiciary; and

(vii) address any other related matters. ${ }^{259}$

The Ringera Committee reported back to the Chief Justice six months later and published in the popular media a list of the judges and magistrates it thought had engaged in corruption. ${ }^{260}$ The Chief Justice then advised the affected judges and magistrates to resign within two weeks or be suspended without pay and face tribunals of inquiry.

There are two principal problems with how the Chief Justice exercised his powers during the "radical surgery." First, the accused judges and magistrates were publicly labeled as corrupt without being informed of the charges against them. ${ }^{261}$ The public naming of the allegedly corrupt judges and magistrates prejudiced the outcome of any subsequent judicial proceedings. As a result, the affected judges and magistrates were condemned well before the commencement of the subsequent tribunals of inquiry. Second, the Chief Justice selected sitting judges to serve on the Ringera Committee. In effect, these judges were now judging their colleagues. Indeed, there were allegations that the members of the Ringera Committee "acted vindictively against their colleagues." ${ }^{62}$ Furthermore, the criteria the Chief Justice used to select the members of the Committee is not clear. Once appointed to this committee, the judges could not be expected to investigate themselves. This raises the question as to who would have investigated them, assuming that there were an objective attempt to investigate corruption in the judiciary as a whole.

Judicial officers may also issue decisions that undermine public confidence in the judiciary, as illustrated by the Saitoti case. The applicant in this case, George Saitoti, was the Minister for Finance when the government approved Goldenberg's creative scheme in the early 1990s. Once word got out that Goldenberg had swindled the

259. Id. $1: 2: 1$.

260. See, e.g., Judges Plot Fightback over Justice Ringera's List of Shame', NATION (Nairobi), Oct. 8, 2003.

261. ICJ, supra note 253, at 19.

262. Joyce Manyasi, Strengthening Democratic Process in the Kenyan Judiciary: Best Practices, Lessons Learnt and Emerging Trends, in JUDICLARY WATCH REPORT: JUDICIAL REFORM IN KENYA 25, 39 (Kenyan Section of the Int'l Comm'n, Judiciary Watch Ser. No. 3, Philip Kichana ed., 2005). 
government, a huge outcry followed and several initiatives were launched to establish how Goldenberg had committed this crime. These initiatives included investigations by committees of Parliament, criminal investigations, and public as well as private attempts to prosecute the perpetrators of the fraud. Shortly after the National Rainbow Coalition (NARC) government assumed office after having won the 2002 general elections, President Mwai Kibaki established a commission of inquiry to investigate the Goldenberg scandal. ${ }^{263}$ The commission was headed by Justice Samuel Bosire, a judge of the Court of Appeal, and was accordingly dubbed the "Bosire Commission."264

Saitoti was unhappy with the report of the Bosire Commission, as it portrayed him unfavorably. Among other things, the Bosire Commission reported that Saitoti "knowingly and illegally allowed [Goldenberg] an enhanced rate of export compensation contrary to the provisions of the Local Manufacturers (Export Compensation) Act. Besides, it was clearly an abuse of his powers as Minister not to have subjected this application to technical evaluation as he did others."265 Saitoti quickly sought judicial review orders in the High Court to quash "the findings, remarks and decisions" of the Bosire Commission and to prohibit the attorney general from bringing criminal charges against him. ${ }^{266}$ The court obliged, finding that the Bosire Commission erred by purporting to review a decision of Parliament and that Saitoti had acted according to the law. The court also noted that Saitoti could not be accorded a fair trial under the circumstances. ${ }^{267}$

The reasoning of the court merits some examination. First, the court considered the National Assembly Public Accounts Committee's (PAC) investigation of the Goldenberg affair and concluded that, in 1995, "the Government followed normal procedures of approval in granting the request by Goldenberg International Ltd." 268 Moreover, the court noted that Parliament had unanimously adopted this report of the PAC. ${ }^{269}$ The court then made reference to section 12 of the National Assembly (Powers and Privileges) Act, which provides that "[n]o proceedings or decision of the Assembly or the committee of privileges acting in accordance with this Act shall be questioned in any court." 270 From this analysis, the court concluded that the Bosire Commission did not have

263. GOLDENBERG AFFAIR, supra note 118, ๆ 1 .

264. See id.

265. Id. ๆ 547.

266. Republic v. Judicial Comm'n of Inquiry into the Goldenberg Affair, (2006) e.K.L.R. 1, 2 (H.C.K.) (Kenya).

267. Id. at 53.

268. Id. at 33 .

269. Id. at 52 .

270. Id at 35 . 
the power to question the decisions of Parliament or committees thereof. ${ }^{271}$ According to the court, once the legislature made a policy decision that the approvals given to Goldenberg were procedural, this decision could not thereafter be questioned by a court of law, let alone an inferior tribunal such as a commission of inquiry.

Second, the court held that, should criminal charges be brought against Saitoti, he would not be able to receive a fair trial because "the comments made in Parliament and by other public officers have already prejudiced the principles of a fair trial," and because the errors and breaches of law by the Bosire Commission "have been widely and serially publicized nationally as truth and law in the past three years."272 The court also reasoned that, because many years had passed without any criminal charges being brought against Saitoti, his constitutional right to a fair trial within a reasonable time would be violated were charges now filed. ${ }^{273}$ Specifically, the court reasoned:

The Applicant is a member of Parliament who in making his contribution in Parliament defended himself on the floor of the August House. Historically Parliaments were in certain jurisdictions called the High Court of Parliament in that as regards matters within their jurisdiction they were regarded as final and could not be reopened elsewhere. There is a semblance of double jeopardy. ${ }^{274}$

Accordingly, the court reasoned that because Saitoti had already been tried in the legislature, it would amount to double jeopardy if he were to be tried in a court of law. Quite apart from the fact that the court stretched the notion of double jeopardy beyond rational limits in its reasoning, the idea that an inquiry by the legislature should constitute a barrier to judicial inquiry is absurd. In any case, the absence of speedy investigations and prosecutions in the Goldenberg affair is arguably attributable to deliberate inaction by the executive. ${ }^{275}$ The idea of a fair trial within a reasonable time should therefore be examined in context, and a court seized of the matter ought to inquire into the circumstances that may have contributed to the failure to institute criminal charges in a timely manner.

The Saitoti decision sets a bad precedent because it renders the

271. Id. at 40 .

272. Id. at 50 .

273. $I d$.

274. Id. at 49 .

275. See GoLDENBERG AFFAIR, supra note 118, 1 757-784. 
report of the Bosire Commission worthless. In all likelihood, any person now adversely mentioned in the report of a commission of inquiry will rush to court, ${ }^{276}$ and when such a person obtains favorable orders, it means that no court of law will try them for any offense they may have committed. This is precisely what happened in the case of Kotut $v$. Bosire. ${ }^{277}$ The decision in Saitoti will therefore make it even harder for the country to fight corruption. ${ }^{278}$ The Saitoti and Kotut decisions also reinforce public perceptions that the courts make political rather than legal decisions so as to protect the interests of the rich and powerful. The fact that the two decisions are not easy to rationalize legally also undermines the authority of the judiciary as a legitimate forum for the resolution of political and other disputes.

Thus in the case of the judiciary, the failure to regulate the powers of appointment of the President and the Chief Justice, and the administrative powers of the latter, may have aided corruption and undermined the legitimacy of the judiciary.

\section{WILL THE NEW CONSTITUTION ENHANCE GOVERNMENT ACCOUNTABILITY?}

Whether the new constitution will enhance accountability depends on the extent to which it addresses the problem of arbitrary power. Therefore, the key question is whether it establishes principles and mechanisms that will circumscribe the exercise of power in all three branches of government.

The new constitution adopts a presidential system of government. Article 130 establishes an executive cabinet consisting of a President, deputy president, and cabinet secretaries. ${ }^{279}$ Article 148 provides that the deputy president shall be nominated by the President-elect and

276. It should be noted that in another case the court declined to issue the orders of certiorari and prohibition, and reasoned that the public interest demanded that the issues raised by the applicant "should be determined in a proper trial, and should not be stayed by the court merely because they relate to issues raised 4, 8,12 or more years ago." Koinange v. Comm'n of Inquiry into Goldenberg Comm'n, (2006) e.K.L.R. 1, 14 (H.C.K.) (Kenya).

277. Kotut v. Comm'n of Inquiry into Goldenberg Comm'n, (2008) e.K.L.R. 1, 52-53 (H.C.K.) (Kenya).; see also Jillo Kadida, Is This the End of the Goldenberg Cases?, DalLY NATION (Nov. 21, 2008, 10:35 PM), http://www.nation.co.ke/News/-/1056/493548/-/tm317h//index.html (reporting the court's decision that the attorney general could not prosecute former Cental Bank Governor Eric Kotut based on the findings of an investigative commission); Judy Ogutu, Goldenberg: Court Also Frees Kotut, STANDARD (Nov. 22, 2008), http://www.standardmedia.co.ke/archives/InsidePage.php?id=1143999884\&cid=4\&.

278. See Paul M. Mwangi, Why Saitoti Ruling is Dangerous for Future of Justice in Kenya, Sunday Nation (Nairobi), Aug. 6, 2006.

279. Constitution, art. 130(1) (2010) (Kenya). 
declared as such by the Independent Electoral and Boundaries Commission. ${ }^{280}$ The cabinet secretaries, who shall not be legislators, are appointed by the President and subject to the approval of the National Assembly, one of the two houses that make up the legislature.281 The President also appoints principal secretaries (formerly permanent secretaries), again subject to the approval of the National Assembly. ${ }^{282}$ The new constitution does not specify the qualifications that cabinet secretaries or principal secretaries must satisfy, with the result that these powers of appointment are not fettered unduly, save that Article 152 caps the number of cabinet secretaries at twenty-two. ${ }^{283}$ Accordingly, it curtails a power that previous presidents have used as a resource to dispense political patronage and subvert the democratic process by, for example, depleting the ranks of the opposition.

Cabinet secretaries may be dismissed under two circumstances. In the first instance, Article 154 allows for their dismissal by the President without the approval of the National Assembly. ${ }^{284}$ Second, Article 152 imposes an obligation on the President to dismiss a cabinet secretary where a majority of the members of the National Assembly adopts a resolution based on the recommendations of a select committee. ${ }^{285}$ This provision seals a loophole that kept ministers with whom the legislature has lost confidence in office.

The role that the cabinet will play in the exercise of executive authority is unclear. Article 131 only provides that the President will exercise executive authority "with the assistance of the Deputy President and Cabinet Secretaries," without clarifying the forms that this assistance will take, or whether the President will be obligated to seek their assistance. ${ }^{286}$ Furthermore, it is unresolved whether the President can bypass the cabinet altogether or make decisions affecting the portfolios of cabinet secretaries without involving or informing them. In this regard, it therefore seems that there is no marked departure from the previous constitution to the extent that the President retains exclusive and unfettered responsibility for the exercise of executive authority. If there is to be a departure from the status quo, the President should be obligated to consult and involve the cabinet in decision making.

Nevertheless, the new constitution makes the cabinet accountable to

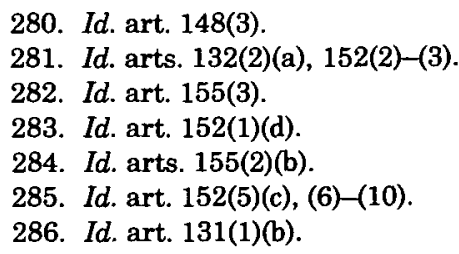


the legislature. Thus Article 153 requires cabinet secretaries to appear before committees of the legislature whenever they are summoned and to provide the legislature with "full and regular" reports concerning matters under their control. ${ }^{287}$ In addition, this article facilitates accountability by requiring that decisions of the cabinet be in writing. ${ }^{288}$

With respect to the Public Service, Article 154 establishes the office of secretary to the cabinet, whose responsibilities include arranging business, keeping the minutes of the cabinet, and communicating the decisions of the cabinet to the Public Service. ${ }^{289}$ The new constitution does not establish principles or mechanisms to guide or regulate the administration of the Public Service or its interaction with the cabinet. Accordingly, there is nothing in the new constitution to prevent the President from continuing with the current practice under which the office of the head of the Public Service and secretary to the cabinet both direct the affairs of the Public Service. The drafters should have taken this practice into account and established mechanisms to regulate how the secretary to the cabinet directs the affairs of the Public Service.

Article 233 establishes a new Public Service Commission, consisting of a chairperson, vice chairperson, and seven other members appointed by the President with the approval of the National Assembly. ${ }^{290}$ The functions of this commission are the same as before with the additional responsibility of hearing and determining appeals in respect of matters relating to the Public Service from the county governments, which constitutes one of the mechanisms for devolution. ${ }^{291}$ Other key functions of the commission include maintaining discipline in the Public Service; promoting national values and principles of governance; and investigating, monitoring, and evaluating the organization, administration, and personnel practices. Notably, this commission is not responsible for directing the affairs of the Public Service. Unlike before, members of the commission can only be removed from office pursuant to the recommendation of a tribunal established by the President with the approval of the National Assembly.292

In a bid to protect public officers from intimidation and to give them security of tenure, Article 236 provides that public officers will not be victimized or discriminated against for carrying out their duties in accordance with the law, or "dismissed, removed from office, demoted in rank or otherwise subjected to disciplinary action without due process of

\footnotetext{
287. Id. arts. $153(3),(4)(b)$

288. Id. art. $153(1)$.

289. Id. art. 154(3).

290. Id. art. $233(1)-(2)$.

291. Id. art. $234(2)(\mathrm{i})$.

292. Id. art. $251(2)-(6)$.
} 
law."293 Therefore, public officers will no longer hold office "during the pleasure of the President," as section 25 of the old constitution proclaimed.294 Accordingly, the new constitution fills a significant loophole in the framework governing the Public Service, namely that public officers were not empowered to resist the illegal instructions of their seniors, ministers, or the President, with the result that they are often accomplices in grand corruption schemes. As examined earlier, public officers looking out for the public interest can easily be intimidated into implementing illegal instructions, which are invariably verbal. Articles 135 and 153 of the new constitution remedy this problem by providing that the decisions of the cabinet and the President must be in writing. ${ }^{295}$ This will empower public officers to require the production of written instructions before taking any action. It will be necessary to align public service regulations, such as the Government Financial Regulations, with these provisions of the new constitution.

Another significant innovation of the new constitution, contained in Article 73, is the introduction of principles on leadership and integrity, which bind all holders of public and state office, including public officers. ${ }^{296}$ In particular, it establishes the principle that the authority assigned to a "State officer" is a "public trust" that must be exercised in a manner that is consistent with the purposes and objects of the constitution. ${ }^{297}$ The new constitution therefore views public officers as the holders of a public trust, who are accountable to the people for the exercise of the powers delegated to them. This promotes public confidence in the integrity of the office.

The new constitution also introduces strict rules on conflicts of interest, which will assist in preventing the abuse of power which so often leads to corruption. Article 75 imposes a duty on state officers to "behave, whether in public and official life, in private life, or in association with other persons, in a manner that avoids any conflict between personal interests and public or official duties." 298 Article 79 also requires that Parliament enact a law to establish an "independent ethics and anti-corruption commission."299 This body's main function will be to ensure compliance with, and enforce, constitutional provisions on leadership and integrity, including conflicts of interest. ${ }^{300}$ Among

293. Id. art. 236.

294. CONSTITUTION, art. 25(1) (1963) (Kenya).

295. CONSTITUTION, arts. 135, 153 (2010) (Kenya).

296. Id. art. 73(2).

297. Id. art. $73(1)(\mathrm{a})(1)$.

298. Id. art. $75(1)(\mathrm{a})$

299. Id. art. 79.

300. Id. 
other things, these provisions will prevent state officers from abusing their power in the process of trying to acquire private property, or pursuing other private interests. These provisions seal a regulatory gap that was created when the Duncan Ndegwa Commission of 1970 recommended that public servants should be allowed to own private property and run businesses. ${ }^{301}$ While the Ndegwa Commission suggested that public servants would only be permitted to do so under strict conditions, even recommending the establishment of the office of an ombudsman to investigate and monitor the performance of public servants, the government did not implement these recommendations. As a result, the decision to permit public servants to own private property and run businesses led to widespread abuse of office and corruption.

In the area of criminal justice, the new constitution enhances objectivity and accountability in investigations and prosecutions. Under Article 157, the state's powers of prosecution will now be exercised by the office of Director of Public Prosecutions (DPP). ${ }^{302}$ The attorney general's primary functions, according to Article 156, will now be to give legal advice to the government and represent it in legal proceedings. ${ }^{303}$ The new constitution notably requires the current attorney general to vacate office no later than twelve months after it takes effect. ${ }^{304}$ This is a vetting exercise, given that the attorney general is considered to be "not just complicit in, but absolutely indispensable to, a system which has institutionalized impunity in Kenya." ${ }^{305}$ The DPP can only take over a criminal suit with the permission of the person or authority who instituted it. In addition, the DPP can only discontinue a prosecution with the permission of the court. Finally, to preclude the abuse of the power to prosecute, the new constitution requires that the DPP's exercise of this power "shall have regard to the public interest, the interests of the administration of justice and the need to prevent and avoid abuse of the legal process." 306 To facilitate the daily application of these principles, there is a need for the legislature to enact guidelines and factors that the DPP should take into account when deciding whether or not to institute criminal proceedings.

Article 93 of the new constitution establishes a Parliament with two houses, namely a National Assembly and a Senate. ${ }^{307}$ The National

301. See Odhiambo-Mbai, supra note 73 , at 121.

302. ConstituTION, art. 157(6) (2010) (Kenya).

303. Id. art. 156(4)(a)-(b).

304. Id. sched. 6 cl. $31(7)$.

305. Human Rights Council, GAOR, Report of the Special Rapporteur on Extrajudicial, Summary or Arbitrary Executions, $\{$ 30, U.N. DoC. A/HRC/11/2/Add.6 (May 26, 2009) (by Philip Alston).

306. CONSTITUTION, art. 157(11) (2010) (Kenya).

307. Id. art. 93(1). 
Assembly will have primary responsibility for legislation and oversight of the executive at the national level. ${ }^{308}$ On the other hand, the Senate is a.mechanism for devolution. ${ }^{309}$ Each house of Parliament will be presided over by a speaker, who shall be an ex officio member as required by Article 106.310 Unlike the present position where the speaker is typically appointed from a pool of current legislators, the new constitution provides that the two speakers will be elected by each house "from among persons who are qualified to be elected as [legislators] but are not such members."311 Among other restrictions, each speaker may be removed from office if the relevant house "so resolves by a resolution supported by the votes of at least two-thirds of its members." 312 The two speakers therefore do not enjoy security of tenure, and may not be able to exercise effective control over the manner in which legislators exercise their collective powers of making policies and laws or over the manner in which legislators hold the executive accountable for its actions.

With respect to the administration of Parliament, Article 127 of the new constitution establishes a Parliamentary Service and a Parliamentary Service Commission, consisting of the Speaker of the National Assembly as the chairperson, seven members nominated by the party or parties in government and opposition parties, and one man and one woman who are "experienced in public affairs" and appointed by Parliament from among persons who are not legislators. ${ }^{313}$ For the first time, persons who are not legislators will sit on this Commission. However, it is not clear how Parliament will go about nominating them. Furthermore, the clerk of the Senate also serves as the secretary of this Commission. ${ }^{314}$ The main functions of the Commission are to provide the services and facilities to ensure that Parliament does its work efficiently and effectively, to constitute offices in the Parliamentary Service, and to appoint and supervise office holders. ${ }^{315}$ Presumably, the Commission will also be responsible for discipline in the Parliamentary Service.

Each house of Parliament will be headed by a clerk appointed by the Commission with the approval of the relevant house according to Article 128. ${ }^{316}$ The clerks do not enjoy security of tenure, and are subject to

308. Id. art. 94(1).

309. Id. art. 95(1).

310. $I d$. art. 106(1)(a).

311. Id. (emphasis added).

312. $I d$. art. $106(2)$ (c).

313. Id. art. 127(2)(a), (c), (d).

314. Id. art. 127(3).

315. Id. art. 127(6)(a)-(b).

316. Id. art. 128(1). 
supervision by the Commission, as they are "offices in the Parliamentary Service."317

Article 117 of the new constitution provides for the powers, privileges, and immunities of the legislature, including "freedom of speech and debate in Parliament." 318 However, it makes no attempt. to circumscribe the exercise of these powers. Nevertheless, Article 1.18 imposes a duty on Parliament to facilitate public participation and involvement in the business of Parliament and its committees, ${ }^{319}$ while Article 119 gives every person the right to petition Parliament "to consider any matter within its authority."320 Article 104 also gives the electorate the right to recall the legislator representing their constituency, and imposes a duty on Parliament to enact legislation that will establish the grounds and procedures according to which a Member of Parliament (MP) may be recalled. ${ }^{321}$ Although these provisions may constitute useful mechanisms for regulating the collective powers of the legislature, they will need to be accompanied by mechanisms that regulate lobbying, conflicts of interest, misconduct, and abuse of power in Parliament.

The absence of such mechanisms has made legislators vulnerable to capture by special interests, which jeopardizes the ability of the legislature to safeguard the public good. It has also brought into question the legislature's ability to hold the executive accountable because its committees, which form a critical part of its arsenal of oversight instruments, often consist of legislators against whom credible allegations of corruption have been made, and who cannot therefore be expected to be genuine champions of the public interest. The provisions of the new constitution dealing with leadership and integrity, including those governing conflicts of interest, therefore provide a much-needed framework for regulating the conduct of legislators.

Finally, in the case of the judiciary, the failure to regulate the President and Chief Justice's powers of appointment and dismissal and the administrative powers of the latter, often aid corruption and undermine the legitimacy of the judiciary. These powers have been exercised in ways that undermine the institutional autonomy of the judiciary and the decisional independence of judicial officers, respectively.

How, then, does the new constitution enhance the independence and accountability of the judiciary? First, it disperses judicial authority.

317. Id. art. 128(2).

318. Id. art. $117(1)$.

319. Id. art. $118(1)(\mathrm{b})$.

320. Id. art. $119(1)$.

321. Id. art. 104. 
Although the Chief Justice is still the head of the judiciary, the new constitution establishes three superior courts (in addition to various subordinate courts): the Supreme Court, the Court of Appeal, and the High Court. ${ }^{322}$ It also establishes the offices of deputy Chief Justice (as the deputy head of the judiciary), who will be the judiciary's chief administrator and accounting officer pursuant to Article 161,323 and chief registrar of the judiciary who will administer the judiciary fund established by Article 173 to enhance the financial autonomy of the judiciary. ${ }^{324}$ It further provides that the Chief Justice will preside over the Supreme Court, while the Court of Appeal and the High Court will be presided over by a judge elected by the judges of these courts from among themselves pursuant to Article $164 .^{325}$

Second, Article 166 of the new constitution gives the judiciary autonomy from the executive. It provides that the President will now appoint the Chief Justice and judges of the superior courts subject to the recommendations of the Judicial Service Commission (JSC) and the approval of the National Assembly. ${ }^{326}$ As in the case of the new PSC, the new constitution broadens the membership of the JSC, which now includes representatives of subordinate courts and practicing lawyers. ${ }^{327}$ Further, it empowers the President to appoint one man and one woman who are not lawyers to "represent the public" in the Commission. ${ }^{328}$

Third, Article 168 of the new constitution circumscribes the power to dismiss judges. Unlike before, the process of removal of the Chief Justice and judges will now be initiated by the JSC. Acting on its own motion, or on the petition of "any person," this Commission is required to hold a hearing regarding the affected judge and to send the petition to the President only when there are legitimate grounds for removal. ${ }^{329}$ Upon receiving the petition, the President is then required to establish a tribunal to inquire into the matter. ${ }^{330}$ The new constitution therefore introduces due process and certainty in the exercise of the power to dismiss judges and is therefore likely to enhance security of tenure and independence of judges.

Another notable feature of the new constitution is that it rids the judiciary of regime actors and provides a framework for the removal of "unsuitable" judges. First, it provides that the Chief Justice shall vacate

322. Id. arts. $163-165$.

323. Id. art. 161(2)(b).

324. Id. art. 173(1).

325. Id. arts. 163(1)(a), 164(2), 165(2).

326. Id. art. 166(1)(a).

327. Id. art 171(2)(d), (f).

328. Id. art. 171(2)(h).

329. Id. art. 168(2)-(4).

330. Id. art. 168(5). 
office within six months after it takes effect. ${ }^{331}$ Secondly, within one year of the constitution taking effect, Parliament must enact a law establishing mechanisms and procedures for vetting the suitability of all judges and magistrates, ensuring they continue to serve in accordance with the values and principles established in Articles 10 and 159.332 While these vetting provisions are commendable, care should be taken to ensure that they do not facilitate witch hunting, a scenario that is plausible given the vagueness of some of the principles established in these articles. For example, a principle such as "patriotism" can be interpreted in different ways, and it would fly in the face of reason or even fairness to dismiss judges on the ground that they have not been patriotic. Additionally, it is debatable whether it would be fair to dismiss judges on the ground that they have not administered justice with due regard to procedural technicalities or on the ground that they have delayed justice in a legal system in which legal procedures lend themselves to such abuses. The need for fairness and due process in the implementation of these provisions is made even more urgent by the fact that the removal, or the process leading to the removal, of judges under these provisions "shall not be subject to question in, or review by, any court." 333 In this regard, Kenya could learn from the experience of other countries, where the performance or competence of judges is assessed by reference to criteria that facilitate objective analysis, such as "willful misconduct" in office, integrity, and conduct prejudicial to the administration of justice, or conduct that brings the judicial office (or judiciary) into disrepute. ${ }^{334}$

A major weakness of the new constitution relates to the appointment of public officers. In many instances, it requires the President to nominate officers (such as the attorney general, the director of public prosecutions, cabinet secretaries, principal secretaries, the Chief Justice, and other judges) for approval by Parliament without establishing criteria for determining the suitability of individuals for these offices. The new constitution assumes that members of Parliament will actually play their role and vet nominees for public office. However, the absence of nomination criteria encourages "horse-trading" among the key political parties, who are thus likely to enter a pact in which the

331. Id. sched. $6 \mathrm{cl}$. 24(1).

332. Id. sched. $6 \mathrm{cl}$. $23(1)$.

333. Id. sched. $6 \mathrm{cl}$. $23(2)$.

334. See generally Stanley Anderson, Judicial Accountability: Scandinavia, California \& the U.S.A., 28 AM. J. COMP. L. 393 (1980) (discussing the worldwide trend towards increasing judicial accountability); Jean E. Dubofsky, Judicial Performance Review: $A$ Balance Between Judicial Independence and Public Accountability, 34 FORDHAM URB. L. J. 315 (2007) (explaining that judicial performance commissions established in Colorado may encroach on judicial independence). 
parties agree not to question the suitability of one another's candidates for office. This would greatly undermine the new constitution's objective of vesting Kenyan professional leaders with integrity. There is thus a need to enact a law establishing suitable nomination and appointment criteria.

\section{REALIZING THE NEW CONSTITUTION}

The new constitution establishes principles and mechanisms that will enhance government accountability. However, these gains will be derailed unless the statutory order is transformed to conform to the values and principles of the constitution. As examined previously, many of the arbitrary powers of government are derived from the statutory order. Democratization initiatives in Africa have tended to concentrate on enhancing ballot-box democracy and enacting new constitutions. While these reforms are important, they have failed to grasp the fact that much of the power of government is exercised by the President through bureaucrats, who regulate the daily lives of citizens and therefore effectively exercise broad delegated powers. In the course of exercising their duties, bureaucrats do not simply implement laws and regulations, but often interpret them. For example, such laws and regulations often give bureaucrats broad discretion. In practice, the breadth and lack of effective regulation of these powers means that the bureaucrats do as they wish for the most part, irrespective of constitutional prescriptions. In addition, judicial review is not an adequate tool for regulating these routine powers since only a few cases will come to the attention of the courts. There is still a need to address the abuse of power by officials at the most basic levels of public administration, such as police constables, clerks at the lands office, municipal clerks, and tax assessors. ${ }^{335}$

In terms of making these low-level officials accountable, a key challenge relates to how the imperial and authoritarian statutory order can be transformed so that it conforms to the demands of constitutionalism. The new constitution addresses this problem by providing, "[a]ll law in force immediately before the effective date continues in force and shall be construed with the alterations, adaptations, qualifications and exceptions necessary to bring it into conformity with this Constitution." 336 In effect, the new constitution gives public administrators and other government officers considerable

335. See H. Kwasi Prempeh, Africa's “Constitutionalism Revival": False Start or New Dawn?, 5 INT'L J. CONST. L. 469, 500 (2007).

336. Constitution, sched. 6 cl. 7(1) (2010) (Kenya). 
latitude in deciding how they will interpret existing statutory laws. Given the limitations of judicial review, this latitude may have the effect that public administrators will continue to be "the real source of the laws governing society's routine social and economic activity."337 In other words, the law will continue to be what the public administrator or police officer declares it to be. In addition, the new constitution has not addressed the need to review the bylaws, regulations, codes of conduct, and governance practices that make up the statutory order and constitute the sources of power for public administrators. These sources of power now need to be brought into conformity with the new constitution.

The new constitution also mandates the development of legislation and administrative procedures required for implementation, with the effect that some of the repressive statutory laws may or may not be repealed. The Sixth Schedule establishes a Commission for the Implementation of the Constitution, which will work together with the attorney general and the Constitutional Implementation Oversight Committee (a select committee of Parliament) to enact the laws that need to be enacted, which are set out in the Fifth Schedule. ${ }^{338}$ Without a doubt, the enactment of these laws will enhance the accountability of the legal order. However, as much of the power of government resides in the statutory order, and political regimes will want to retain as much power as possible, the process of enacting laws to facilitate the realization of these constitutional principles and mechanisms will be highly contentious. For this reason, the work of the Commission for the Implementation of the Constitution needs to be participatory and accountable.

The establishment of a credible regime of administrative law also offers a useful avenue for democratizing the exercise of power. While constitutional law sets out the broad powers of the executive and other branches of government, administrative law plays the important role of ensuring that public agencies and public officers do not abuse the discretionary powers that are given to them by statutes. It is therefore a critical tool for the realization of limited government that adheres to the rule of law ideal. Administrative law performs its role by establishing democratic principles and procedures that regulate the exercise of power, such as transparency and procedural fairness. It also plays a critical role in fostering participation by interested parties in the decision-making processes of government.

In this regard, the provisions of the new constitution on fair

337. Prempeh, supra note 335 , at 498 .

338. CONSTITUTION, sched. 5, sched. 6 cl. 5(1), (6)(b) (2010) (Kenya). 
administrative action are critical. Article 47 provides, "[e]very person has the right to administrative action that is expeditious, efficient, lawful, reasonable and procedurally fair." 339 It further provides that every person has "the right to be given written reasons where his or her right or fundamental freedom has been or is likely to be adversely affected by administrative action." 340 The new constitution also imposes a duty on Parliament to enact a law giving effect to these rights.

This right to fair administrative action may enhance the participation of the citizenry in, and the accountability of, the exercise of power. First, it can enhance the rights and expectations of citizens in governmental processes, who would then be in a better position to demand responsive administrative action. Second, it can enhance the accountability of public officers, who are likely to perform better because they know that their actions are being scrutinized by the citizenry.

But the citizenry can only take advantage of the values, principles, and mechanisms established by the new constitution if they are sufficiently empowered. In this respect, legal empowerment initiatives are crucial. Such initiatives would include legal literacy training, increased availability of legal assistance, and public interest litigation. In particular, the capacities of disadvantaged and vulnerable groups must be enhanced by the State and nongovernmental organizations so that they can make better use of the democratic spaces created by the new constitution.

\section{CONCLUSION}

This article has argued that abuse of power and corruption in Kenya can be attributed to the absence of effective regulatory principles and mechanisms. Typically, the law has granted executive, legislative, and judicial actors broad power without establishing effective mechanisms to circumscribe their exercise. The new constitution promises to reduce abuse of power and corruption, in so far as it establishes much-needed principles and mechanisms for effective regulation of governmental power. However, the constitution alone will not enhance government accountability. This is because much of the power of government is found in a statutory order that gives executive, legislative, and judicial actors vast discretionary power, which have often fueled corruption. Therefore an urgent need arises to align this statutory order with the values and principles of the new constitution, and to empower citizens to demand accountability from government.

339. Id. art. $47(1)$.

340. Id. art. $47(2)$. 